Number 140 - September 2012

\title{
THE PAST AND FUTURE OF KNOWLEDGE-BASED GROWTH
}

Holger Strulik

Klaus Prettner

Alexia Prskawetz

Georg-August-Universität Göttingen 


\title{
The Past and Future of Knowledge-based Growth
}

\author{
Holger Strulik ${ }^{\dagger}$ \\ Klaus Prettner ${ }^{\ddagger}$ \\ Alexia Prskawetz ${ }^{\S}$
}

September 2012.

\begin{abstract}
Conventional R\&D-based growth theory argues that productivity growth is driven by population growth but the data suggest that the erstwhile positive correlation between population and productivity turned negative during the 20th century. In order to resolve this problem we integrate R\&D-based innovations into a unified growth framework with micro-founded fertility and schooling behavior. The model explains the historical emergence of $R \& D$-based growth and the subsequent emergence of mass education and the demographic transition. The ongoing child quality-quantity trade-off during the transition explains why in modern economies high growth of productivity and income is associated with low or negative population growth. Because growth in modern economies is based on the education of the workforce, the medium-run prospects for future economic growth - when fertility is going to be below replacement level in virtually all developed countries - are much better than suggested by conventional R\&D-based growth theories.

Keywords: R\&D, declining population, fertility, schooling, human capital.

JEL: J13, J24, O10, O30, O40.
\end{abstract}

\footnotetext{
${ }^{*}$ We would like to thank Carl-Johan Dalgaard, Oded Galor, Franz Hof, Peter Howitt, and Dirk Krueger for helpful comments.

${ }^{\dagger}$ University of Goettingen, Department of Economics, Platz der Goettinger Sieben 3, 37073 Goettingen, Germany; email: holger.strulik@wiwi.uni-goettingen.de.

${ }^{\ddagger}$ Harvard University, Center for Population and Development Studies, 9 Bow Street, Cambridge, MA 02138, USA, email: kprettne@hsph.harvard.edu.

${ }^{\S}$ Vienna University of Technology, Vienna Institute of Demography, Austrian Academy of Sciences and Wittgenstein Centre for Demography and Global Human Capital.
} 


\section{INTROdUCTION}

A characteristic feature of economic theories designed to explain the performance of human societies over the very long run is that they are emphasizing the interaction between economic and demographic variables as crucial for our understanding of economic development (see Galor, 2005, 2011 for surveys). Broadly speaking, these "unified growth theories" explain why the demo-economic history of countries or regions can be conceptualized as subdivided into two periods: the Malthusian era and the modern era. During the Malthusian era fertility is high, fueled by (relatively small) productivity gains the population is gradually expanding, and income is almost constant at a low level. During the modern era fertility is low and productivity gains translate into perpetual economic growth at high and (ideally) constant rates. Both eras are connected by a demographic transition during which fertility declines and economic growth takes off. Usually it is assumed that the process converges from above towards a state of stationary or slowly growing population.

Actually, however, the idea that the demographic transition stops at replacement level is refuted by empirical evidence. The total fertility rate (TFR) fell below replacement level in the 1970s in Europe and Japan, in the 1980s in North America and Australia, and in the 1990s in the Asian Tiger countries (Bongaarts, 2001). It is now below replacement level in all 50 European countries but Turkey (where it is at 2.15) and in more than 80 countries in the world (UN, 2011). Table 1.A, compiled from UN (2011), shows the most recently observed TFR for the G-8 countries, i.e. those countries that we usually associate with production at the "frontier of technological knowledge" (Aghion and Howitt, 2009). In every country that contributes substantially to innovation-based, R\&D-driven growth the TFR is below replacement level (i.e. TFR below 2.1).

\begin{tabular}{crll} 
TABLE 1.A: TFR FOR THE G-8: 2005-10 \\
\hline \hline USA & 2.07 & France & 1.97 \\
U.K. & 1.83 & Canada & 1.65 \\
Italy & 1.38 & Germany & 1.36 \\
Russia & 1.44 & Japan & 1.32 \\
\hline \hline
\end{tabular}

\begin{tabular}{ll} 
TABLE 1.B: TFR USA 2008 \\
\hline \hline Non-Hispanic white & 1.83 \\
Asian-American & 2.05 \\
Black & 2.11 \\
Hispanic & 2.90 \\
\hline \hline
\end{tabular}

Among the developed countries the U.S. is unique in displaying a TFR close to replacement level. Table 1.B, compiled from U.S. National Center for Health Statistics (2010), shows that this achievement originates solely from the high TFR of the Hispanic part of the population. The TFR of non-Hispanic whites (1.83), for example, is close to that of their European forefathers. Assuming that fertility behavior of immigrants is at least partly rooted in the fertility norms of the country of origin we expect fertility of the Hispanic population in the U.S. to fall below replacement 
level with ongoing fertility transition in the countries of origin. Some Latin American countries (e.g. Chile, Brazil, Cuba) already display fertility below replacement and for other countries this seems to be likely in the future. In 2008 the United Nations predicted according to their mediumvariant projection that every country converges towards a TFR of 1.85 in the medium run, i.e. a fertility pronouncedly below replacement level (UN, 2008). Inspired by some recent mild recoveries of fertility the latest UN projection assumes again convergence towards replacement level, albeit with heavy undershooting; for Europe, Asia, and Latin America the TFR is predicted to remain below replacement level over the whole 21st century (UN, 2011).

According to conventional theories of R\&D-based growth, the fact that the population is declining entails a grim economic outlook for modern economies. Models of the first generation (Romer, 1990, Aghion and Howitt, 1992) provide the result that growth of aggregate productivity (TFP) is linearly related to population size. Thus, a declining population implies vanishing growth of productivity and income per capita. According to models of the second generation (Jones, 1995, Kortum, 1997, Segerstrom, 1998), TFP growth is linearly related to population growth. ${ }^{1}$ Actually these models are not designed to take fertility below replacement level into account. A declining population would, strictly speaking, imply negative productivity growth. If such behavior is ruled out by imposing a non-negativity constraint, a declining population would lead to stagnation of productivity and income per capita at the corner solution. ${ }^{2}$

Advocates of conventional R\&D-based growth theory emphasize that these models should not be applied to single countries but to markets because ideas can cross borders. It is thus important to notice that fertility below replacement level is not an abnormal feature of some strange country but globally observed in virtually every country that could be associated with an advancement of world technology through R\&D-based growth.

Fortunately, the empirical evidence does not support the prediction of conventional R\&D-based growth theory. In fact, in Section 2 we argue that the data supports the opposite. Productivity growth is negatively associated with population growth during the 20th century, across countries as well as over time. In order to explain this phenomenon we develop a novel R\&D-based growth

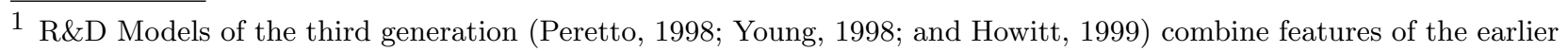
generations by investigating quality $R \& D$ and variety $R \& D$. Assuming that there exist no knowledge spillovers between quality and variety $R \& D$ they predict that only variety growth is essentially associated with population growth while constant quality growth requires a constant population. Allowing for knowledge spillovers between sectors re-establishes the positive association between population growth and productivity growth, see Li (2000).

2 A quantitative exercise employing the conventional R\&D-based growth model (Jones, 2003) expects R\&D-based growth to converge to 0.06 percent annually assuming - in contrast to the UN population predictions - that the labor force in the G-5 countries continues to grow at 1.2 percent annually.
} 
theory. The new theory proposes a refined view on the human factor in productivity growth which consists of three elements.

Firstly, we follow Romer (1990) and argue that it is not the sheer number of workers $(L)$ that propels the creation of ideas and the advancement of productivity but the total amount of knowledge embodied in these workers, i.e. aggregate human capital $(H)$. The most intuitive aggregation is probably that total human capital is given by human capital per worker $h$ times the number of workers $(H=h \cdot L)$. Utilizing this notion of human capital and endogenizing the incentive to acquire it through costly schooling, a couple of papers have already demonstrated that human capital growth can take over the role of population growth in R\&D-based growth models by predicting that productivity growth can be sustained with constant or declining population as long as human capital is accumulated rapidly enough. ${ }^{3}$

But the so far existing literature has left unsolved the problem of the productivity reversal, i.e. why growth of population and productivity were positively related during the most of human history and negatively related in the 20th century. To be specific, acknowledging that aggregate human capital, $H=h \cdot L$, matters for productivity growth it is straightforward to see why productivity growth is positively associated with increasing $h$. The yet unsolved puzzle is why, simultaneously, productivity growth is negatively associated with increasing $L$ since about the early 20 th century, although it has certainly been positive before, i.e. for most of human history.

In order to account for the reversal in the association between population growth and productivity we, secondly, introduce an interaction of quantity and quality of the workforce into R\&D-based growth theory. The interaction originates from a micro-founded trade-off that allows parents to substitute child quality for child quantity such that $h$ rises and $L$ falls. ${ }^{4}$ The child quantity quality trade-off plays also a crucial role in the literature on the demographic transition and in unified growth theory. The causes and consequences of declining population, however, have not yet been investigated in this literature. Also, R\&D-driven productivity growth has not yet been investigated in a unified growth framework. To our best knowledge the present paper is novel in this regard as well. ${ }^{5}$

3 See, among others, Funke and Strulik (2000), Dalgaard and Kreiner (2001), Strulik (2005), Grossmann (2009).

4 See Becker (1960), Becker and Lewis (1973), and Becker et al., (1990). For empirical support see, among others, Rosenzweig, Wolpin (1980) Rosenzweig (1990) Hanushek (1992) Becker et al. (2010), and Lee and Mason (2010).

${ }^{5}$ For unified growth theory see, among others, Galor and Weil (2000), Galor and Moav (2002, 2004), Galor et al. (2009), De la Croix and Doepke (2003, 2004), Moav (2005); see Galor (2005, 2011) for surveys. A few articles have integrated endogenous fertility into an R\&D-based growth framework, notably Jones (2001), Connolly and Peretto (2003) and Growiec (2006). But the interaction with education and the quantity-quality trade-off remained unresearched. 
The third element is to discover the mechanism according to which the quantity-quality tradeoff leads to more aggregate human capital, i.e. to explain why $h$ rises more strongly than $L$ falls. To see how the mechanism works, consider a unit increase of education expenditure in company with a unit reduction of fertility such that total child expenditure remains constant. Such a oneto-one quantity-quality substitution is not neutral. It sets free parental time because less time is needed for child rearing. The time gained can be used to earn additional income, which in turn is spent on consumption and on children's education. This means the original one-to-one substitution leads actually to a situation where children's education increases by more than fertility falls. As a consequence, aggregate human capital increases. Since this mechanism is based on interaction in the budget constraint (and not from specifications of the utility function) we are thus confident that our results hold with some generality.

The model explains the following evolution of knowledge-based growth. For most of human history, productivity growth originated from learning-by-doing and was thus positively associated with population growth. Eventually, through growing $L$, market R\&D became worthwhile. After this first industrial revolution the economy expanded through $R \& D$-based growth and high population growth (from today's perspective) and productivity and population were still positively associated. Eventually, however, human capital became precious enough for mass-education to become worthwhile. A demographic transition was initiated during which subsequent generations of parents decided to have less children and to educate them better. During the fertility transition the quantity-quality mechanism explained above was at work: the increase of individual human capital endowments overcompensated the associated decline of raw labor such that aggregate human capital and income per capita started to grow at unprecedented rates while population growth declined.

The theory thus suggests a productivity reversal. Before the onset of the fertility transition, increasing fertility and population growth contributed positively to productivity growth. The "old" R\&D-based growth theory is thus not completely abandoned. It is still present as a temporary, intermediate phase during which $R \& D$ is worthwhile but the fertility transition has not yet been initiated. When the child quantity-quality trade-off becomes operative, productivity growth becomes negatively associated with population growth, as observed during and after the 20th century. This negative association is bi-causal and holds irrespective of family size, that is, in particular, also for fertility below replacement level. The refined model thus provides a much brighter outlook for 
the future of R\&D-based growth in contemporary societies. It predicts high growth of income and productivity when fertility is close to or below replacement level.

The paper is organized as follows. The next section explores the empirical association between population growth and productivity growth. Section 3 sets up the R\&D-based growth model. Section 4 analyzes the balanced growth path and provides the results from comparative static analysis. Section 5 calibrates the model to capture the long-run development of an aggregate G-7 economy. It demonstrates that the theory can correctly predict the productivity reversal and matches other macroeconomic aggregates (fertility, education, R\&D labor input and GDP per capita) reasonably well. Furthermore the model offers novel insights about the onset of innovation based growth (the first Industrial Revolution) and mass education driven growth (the second Industrial Revolution). We then use the model to predict economic growth for the 21st and 22nd century given the high-, medium-, and low-fertility projections of the UN. We conclude with a speculative outlook for future economic development.

\section{The Productivity Reversal}

It is a well known fact that for most of human history the growth of productivity and population were positively associated because productivity growth allowed the subsistence of larger families (e.g. Ashraf and Galor, 2011) or because a larger population meant a larger number of tinkerers producing more ideas (Kremer, 1993). We are not challenging this established fact of pre-modern human history. In modern times, however, specifically after the onset of the fertility transition and of $\mathrm{R} \& \mathrm{D}$ as a market activity, the erstwhile positive association between productivity growth turned negative. Across countries, $\mathrm{R} \& \mathrm{D}$-driven productivity growth is high in countries with low or negative population growth. Over time, within the group of countries at the knowledge frontier, productivity growth is increasing when fertility is decreasing. These are the observations which are hard to square with conventional R\&D-based growth theory. ${ }^{6}$

For the 20th century a negative association between population growth and income or income growth has already been documented by several studies (e.g. Brander and Dowrik, 1994, Kelley and Schmidt, 1995, Ahituv, 2001, Li and Zhang, 2007, and Herzer et al., 2012). The association between average annual growth of population and TFP growth across countries for the period 1950 to 2000

6 Taking the productivity reversal into account, the title of Kremer's paper could be improved by exchanging "Population growth and technology change: one million B.C. to 1990" for "Population growth and technology change: one million B.C. to 1900". 
is shown in Figure 1 (calculated from the data in Baier et al, 2006). Across all countries for which data is available (identified in the Figure by blue crosses) the simple correlation is clearly negative (see Bernanke and Guerkaynak, 2001, for a similar finding).

As already mentioned in the Introduction, R\&D-based growth is probably not well measured at the country-level because the locally created knowledge diffuses internationally. But knowledge spillovers decline with distance and are smaller across countries than within countries (Jaffe et al., 1993, Keller, 2002, Bottazzi and Peri, 2003). If conventional R\&D-based growth theory is right we would thus expect that at least some of the high TFP growth generated in countries where population growth was high to be visible in the data. But Figure 1 seems to suggest the opposite.

Figure 1: Population Growth vs. TFP Growth 1950 - 2000

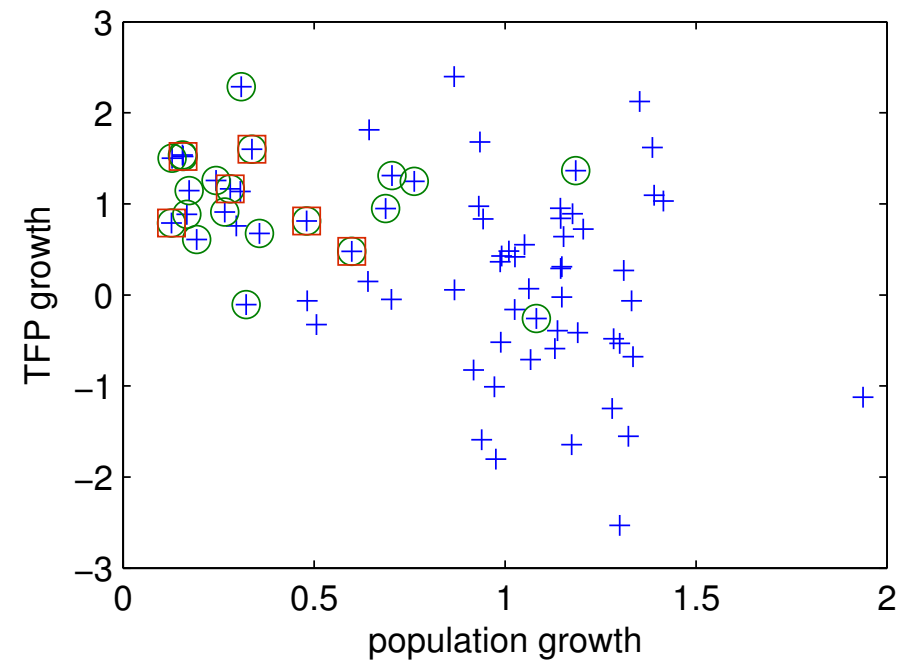

Growth rates are average annual growth rates 1950-2000 calculated from Baier et al. (2006). Blue crosses: all available countries, green circles: OECD countries, red squares: G-7 countries.

If we acknowledge the fact that less developed countries - i.e. in the places where usually population growth is highest - do not much advance TFP growth by market R\&D activities and focus just on OECD countries (green circles) the allegedly positive association between population growth and productivity growth is still not visible in the data. Extending the argument a step further, and assuming that R\&D-based growth theory applies foremost to the G-7 countries, i.e. a small group of countries that pushes the world technology frontier (red squares), the predicted positive association remains invisible. If anything, the scatterplot suggests a negative association. ${ }^{7}$

\footnotetext{
${ }^{7}$ The G-7 countries accounted for 84 percent of worldwide R\&D spending in 1995 (Keller, 2009). Data for Germany is missing in Figure 1 and the regressions below. But given Germany's very low fertility rates and relatively high TFP growth rates, it can be conjectured that including Germany would certainly corroborate the result.
} 
In order to explore the association between TFP and population growth a bit further, we constructed TFP growth rates and growth rates of the labor force in ten year steps between 1940 and 2000 for a sample of 67 countries using the data from Baier et al. (2006). This allows us to expand the sample size considerably and, more importantly, it enables us to control for country- and timespecific fixed effects. Fixed effects would also capture catch-up growth induced by an initially low output per worker after WWII.

The model that we estimate reads

$$
g_{i, t}=\beta_{1}+\beta_{2} \Delta \log \left(L_{i, t}\right)+\epsilon_{i}+\kappa_{t}+u_{i, t}
$$

where $g_{i, t}$ is average TFP growth in country $i$ between time $t$ and $t-1, \Delta \log \left(L_{i, t}\right)$ is the average growth rate of the labor force in county $i$ between time $t$ and time $t-1, \epsilon_{i}$ are country specific fixed effects, $\kappa_{t}$ are time specific fixed effects, $u_{i, t}$ is the error term and $\beta_{1}$ and $\beta_{2}$ are the coefficients to be estimated. The results are reported in Table 2 for the total sample referred to as "World", the OECD countries, and for the G-7 countries except Germany.

Table 2: Population Growth And TFP Growth: 1940-2000

\begin{tabular}{lrrrrrr}
\hline \hline & \multicolumn{3}{c}{ two-way fe } & \multicolumn{3}{c}{ pooled OLS } \\
& World & OECD & G-7 & World & OECD & G-7 \\
\hline pop. growth & -0.89 & -1.11 & -1.04 & -1.21 & -1.16 & -0.77 \\
t-value & -5.29 & -3.79 & -0.89 & -8.61 & -4.79 & -0.98 \\
$R^{2}$ & 0.36 & 0.33 & 0.17 & 0.17 & 0.14 & 0.03 \\
$N$ & 402 & 156 & 36 & 402 & 156 & 36 \\
\hline \hline
\end{tabular}

Dependent variable: TFP growth; see Appendix for list of countries.

As Table 2 documents, the central qualitative result of a negative correlation between TFP growth and population growth is robust to model specifications with respect to country- and time-specific fixed effects. The correlation is significantly negative for the world and the OECD. For the G-7, which is actually only a "G6" since data for Germany is missing, the estimate loses precision. Given that there are only six countries, including one prominent outlier (the US), this seems to be a natural result. In any case, we do not find supporting evidence for a positive correlation between TFP growth and population growth. The estimated slope is about minus one across samples, suggesting that a decrease of population growth translates one-to-one into an increase of TFP growth. Given the possibility of reverse causality, these exercises are, of course, not sufficient to reject a potential causal positive impact of population growth on TFP growth. But it is hard to come up with a mechanism 
Figure 2: Population Growth and TFP Growth: G-7 Countries, 1860-2000
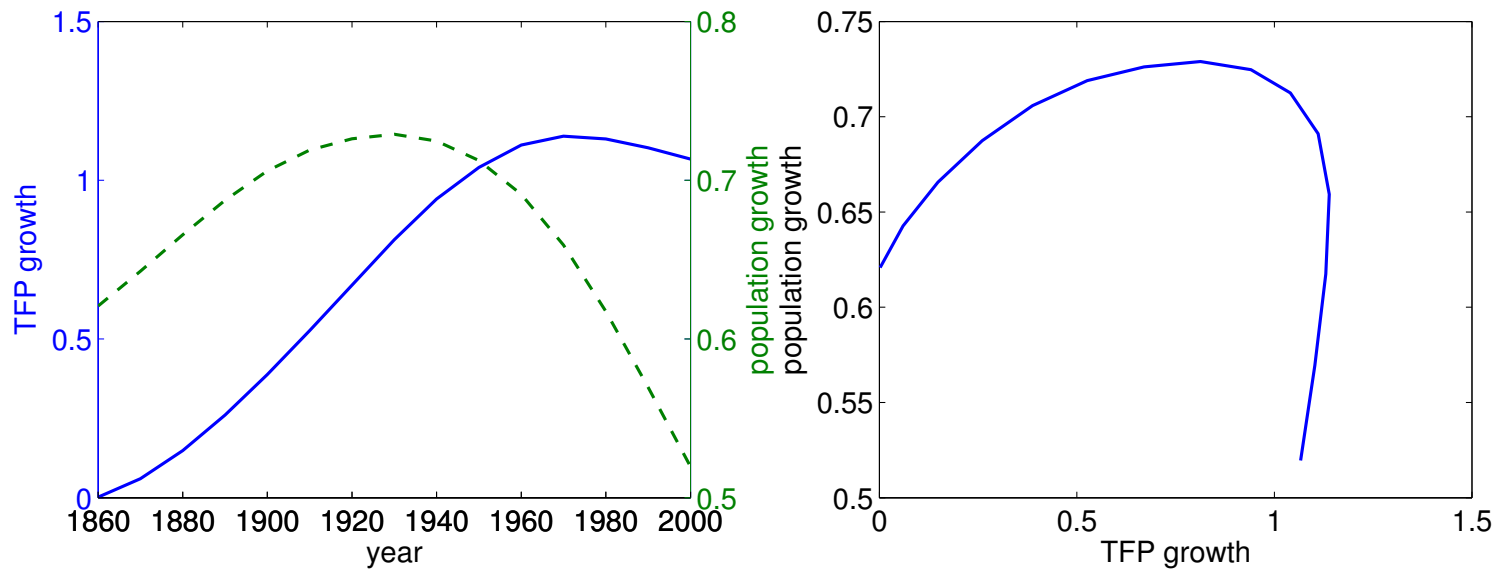

Data sources: see Appendix. Time series smoothed with Hodrick Prescott filter (factor 100). Left: solid (blue) line: TFP growth; dashed (green) line population growth. Right: The implied trajectory for population growth-TFP growth.

that would be so strong that it overturns the allegedly positive impact such that it becomes invisible in the data.

We next expand the time window to cover also a period before the onset of the fertility transition in today's fully developed countries. Related exercises of quantitative economic history have singled out the G-5 countries as the most important drivers of the world technology frontier (Jones, 2003, Ha and Howitt, 2006). Since the data is available we extend the set of countries a bit towards the G-7 in favor of more general results (i.e. US, UK, Germany, France, Japan, Canada, and Italy). Anyway, the pictures that we obtain for the G-7 and G-5 look very similar. From the individual countries' time series we compute population-weighted average time series for population growth and TFP growth during the 1860-2000 period. We smooth the obtained series of annual average growth rates using the Hodrick-Prescott (1997) filter and a smoothing parameter of 100 in order to uncover the long-run trend.

The panel on the left hand side of Figure 2 shows the average trend growth rates for the G-7 countries. The blue (solid) line shows TFP growth and is scaled along the axis on the left hand side. The green (dashed) line shows population growth and is scaled along the axis on the right hand side. At the beginning, before the onset of the fertility transition, population growth was relatively high (from today's perspective) and TFP growth was very low. At the end, population growth is small but still positive due to falling old age mortality, and TFP growth is relatively large (from 19th century perspective). If we imagine today's LDCs where the G-7 were a century ago, it is easy to 
rationalize the observed negative correlation between population growth and TFP growth observed across countries in the larger sample.

Until the year 1920, which roughly coincides with the onset of the fertility transition in the G-7 countries, population growth and TFP growth are jointly rising, as observed by Kremer (1993). ${ }^{8}$ Afterwards, fertility declines and TFP continues to rise further, reaching an unprecedented high in the 1970s, roughly at the time when fertility falls below replacement level in most of the G-7 countries. Afterwards, the Hodrick-Prescott filter identifies mildly decreasing TFP growth while population growth continues to decline. The panel on the right hand side of Figure 2 shows the semicircle described by the joint evolution of population growth and TFP growth with maximum reached in 1920, around the time of the onset of the fertility transition.

During the period of investigation average years of schooling in the G-7 increased continuously from 0.57 years in 1860 to 11.9 years in 2000 (see Appendix for computational details). In 1920, at the time of the fertility reversal, G-7 children had on average 4.0 years of eduction. One attempt to square conventional R\&D-based growth theory with these facts could be to argue for long gestation lags of human capital. In that case the high TFP growth at the end of the 20th century could have been accomplished by relatively old scientists and engineers of the relatively large but less well educated cohorts born 1920-1950. The alternative - that we propose below - is to acknowledge a child quantity-quality trade-off. In that case it is possible that the high TFP growth rates at the end of the 20th century have been accomplished by relatively small cohorts of young and well educated scientists and engineers born after the 1950s.

\section{THE ModeL}

3.1. Households. Consider an economy populated by three overlapping generations, children, young adults, and old adults. Children consume the provisions received by their parents and old adults consume their savings plus interest. Young adults supply one unit of labor and decide how to split their income between current consumption and future consumption, how many children they want to have, and how much they want to spend on their children's education.

In order to derive the main results conveniently and to get explicit solutions, we make a number of simplifying assumptions. Each unisex household consists of one parent (which avoids to tackle

\footnotetext{
8 Reher (2004) identifies the onset of the fertility decline for the G-7 as 1900 for Germany and France, 1910 for
} England, 1915 for Canada, 1925 for the US and Italy, and 1950 for Japan. 
matching problems), there is no explicit consideration of mortality (which avoids problems of uncertain survival), children are a continuous number (which avoids problems of indivisibility), and the motive of child expenditure is non-operational (which avoids problems of maximizing dynastic value functions). This means that parents' motivation to spend on children's education is not driven by the anticipation of the increase of children's utility caused by this expenditure but by a "warm glow" of giving (Andreoni, 1989) or the desire for having "higher quality" children (Becker, 1960).

To be specific let $c_{t}^{1}$ and $c_{t}^{2}$ denote consumption of the young and old in period $t$. The currently young, facing a gross interest rate $R_{t+1}$, and making a savings decision $s_{t}$, expect future consumption $c_{t+1}^{2}=R_{t+1} s_{t}$. A young adult's human capital is denoted by $h_{t}$ and the wage per unit of human capital is denoted by $w_{t}$. Let $n_{t}$ denote the number of children and $\tau$ the time cost involved in having a child. ${ }^{9}$ Children acquire a minimum (informal) education $\bar{e}$ by observing and imitating parents and peers at work. To increase education beyond this minimum level parents may spend $e_{t}$ per child, conceptualized in the Beckerian sense as child quality expenditure. Education of the current period's children determines human capital endowment of next period's adult generation $\left(h_{t+1}\right)$. Since the parameters of education and future wages are given to the single adult, having expenditure on education, or next period's human capital, or wage income of their children in the utility function leads to similar results. Summarizing, young adults solve the problem

$$
\max _{c_{t}, s_{t}, e_{t}, n_{t}} u_{t}=\log c_{t}^{1}+\beta \log \left(R_{t+1} s_{t}\right)+\gamma \log \left(\bar{e}+e_{t}\right)+\eta \log n_{t}
$$

subject to the budget constraint $w_{t} h_{t}\left(1-\tau n_{t}\right)=c_{t}^{1}+s_{t}+n_{t} e_{t}$. All variables have to be non-negative. The positive parameters $\beta, \gamma$, and $\eta$ denote the weights of future consumption, child expenditure, and family size for utility capturing the importance of these elements relative to current consumption. In order to get a meaningful problem in which a population of positive size exists, we assume $\eta>\gamma$, which ensures that $n_{t}>0$. With respect to education, however, no such logical argument can be made, implying that $e_{t}$ could be positive or zero depending on whether the non-negativity constraint $e_{t} \geq 0$ is binding or not.

From the first order conditions we obtain the solution (2) for consumption and savings regardless of whether education is interior or at the corner.

$$
c_{t}=\frac{1}{1+\beta+\eta} \cdot w_{t} h_{t}, \quad s_{t}=\frac{\beta}{1+\beta+\eta} \cdot w_{t} h_{t}
$$

\footnotetext{
${ }^{9}$ Following Galor (2005) $n_{t}$ could be interpreted as the number of children surviving up to adulthood, implicitly assuming that child costs are only associated with surviving children.
} 
For child quantity and quality there exists a threshold at $z \equiv \eta \bar{e} /(\gamma \tau)$. If income falls below the threshold parents do not invest in education and focus on maximizing child quantity. In particular we obtain from the first order conditions

$$
\begin{gathered}
e_{t}= \begin{cases}0 & \text { for } w_{t} h_{t}<z \\
\frac{\gamma \tau w_{t} h_{t}-\eta \bar{e}}{\eta-\gamma} & \text { otherwise }\end{cases} \\
n_{t}= \begin{cases}\frac{\eta}{(1+\beta+\eta) \tau} & \text { for } w_{t} h_{t}<z \\
\frac{(\eta-\gamma) w_{t} h_{t}}{(1+\beta+\eta)\left(\tau w_{t} h_{t}-\bar{e}\right)} & \text { otherwise }\end{cases}
\end{gathered}
$$

Once income surpasses the threshold $z$ a fertility transition is initiated: further rising income leads to declining fertility and increasing expenditure for education. While education expenditure is not bounded, fertility arrives at a lower bound as income approaches infinity.

$$
\lim _{w_{t} h_{t} \rightarrow \infty} n_{t}=\underline{\mathrm{n}} \equiv \frac{\eta-\gamma}{(1+\beta+\eta) \tau} .
$$

Notice that $\underline{\mathrm{n}}$ may fall below the replacement rate of unity. In particular, $\underline{\mathrm{n}}<1$ for $\tau>(\eta-\gamma) /(1+$ $\beta+\eta)$.

3.2. Education. Education $e_{t}$ is transformed into human capital of the next generation of young adults via a schooling technology. A reasonable technology does not just translate expenditure into human capital but controls also for the costs of schooling. These costs can be conveniently approximated by the wage $w_{t}$, i.e. the cost of a unit of human capital of the current adult (teacher-) generation. The simplest conceivable schooling technology is given by $h_{t+1}=A_{E}\left(e_{t} / w_{t}\right)+\bar{e}$ in which $A_{E}$ signifies general productivity of schooling. Without education expenditure, human capital of the next generation consists of basic skills picked up from observing and mimicking parents and peers. Inserting (3) into the schooling technology provides a simple equation of motion for human capital: ${ }^{10}$

$$
h_{t+1}=\frac{A_{E}}{\eta-\gamma}\left(\gamma \tau h_{t}-\frac{\eta \bar{e}}{w_{t}}\right)+\bar{e}
$$

\footnotetext{
${ }^{10}$ Whereas some elements of the schooling function could be made more general, controlling for the teacher- generation's wage is essential for stability. Otherwise human capital would grow hyper-exponentially, driven by increasing $h_{t}$ and rising $w_{t}$. A similar control for the current state of quality is known to be essential for stability in R\&D-driven quality improvements of products, see e.g. Li (2000).
} 
With growing income the growth rate of human capital becomes a constant.

$$
\lim _{w_{t} h_{t} \rightarrow \infty} \frac{h_{t+1}}{h_{t}}=\Delta_{h} \equiv A_{E} \frac{\gamma \tau}{\eta-\gamma}
$$

Provided that $\Delta_{h}$ is larger than unity the model supports perpetual long-run growth. We discuss the case of infeasible long-run growth and a potential link between aggregate knowledge $A$ and education efficiency $A_{E}$ in the Conclusion.

3.3. Firms: Overview. The setup of firms and markets follows closely Romer (1990) and Jones (1995). The economy consists of three sectors: The R\&D-sector is perfectly competitive and employs scientists to create new ideas in the form of blueprints, manifested in patents. A patent is needed as fixed input to produce a specialized capital good. Purchase of a patent allows a capital goods producer to transform one unit of raw capital, i.e. one unit of individual's savings, into one blueprintspecific machine. A perfectly competitive final goods sector uses these machines and workers to assemble a consumption aggregate.

Since the firms' side of the model - aside from the special role of human capital and the possibility of a corner solution - coincides with the Romer-Jones setup, description can be brief.

3.4. Final goods sector. The final goods sector operates the following piecewise defined CobbDouglas production technology

$$
Y_{t}=B_{t}\left(H_{t}^{Y}\right)^{1-\alpha} \sum_{i=1}^{A_{t}} x_{i, t}^{\alpha}
$$

for $i \geq 1$, i.e. when there is $\mathrm{R} \& \mathrm{D}$ and $Y_{t}=A_{0} B_{t}\left(H_{t}^{Y}\right)^{1-\alpha}$ with $A_{0}<1$ for $i=0$. Here, $Y_{t}$ is output, $H_{t}^{Y}$ is employment, $B_{t}$ is the technological level achieved through learning-by-doing, and $A_{0}$ is a normalizing constant for output before the onset of market R\&D activities. The parameter $\alpha$ is the capital share in final goods production, $x_{i, t}$ is the amount of a certain machine $i$ used in final goods production and $A_{t}$ is the number of available differentiated inputs. Facing a wage $w_{t}$ per unit of human capital, and rental prices $p_{i, t}$ for capital inputs $i=1, \ldots, A$, demand for labor and differentiated inputs fulfils

$$
\begin{aligned}
w_{t} & =(1-\alpha) B_{t}\left(H_{t}^{Y}\right)^{-\alpha} \sum_{i=1}^{A_{t}} x_{i, t}^{\alpha}=(1-\alpha) \frac{Y_{t}}{H_{t}^{Y}} \\
p_{i, t} & =\alpha B_{t}\left(H_{t}^{Y}\right)^{1-\alpha}\left(x_{i, t}\right)^{\alpha-1} .
\end{aligned}
$$


3.5. Capital Goods Production. Producers of specialized inputs transform one unit of raw capital into one unit of specialized capital such that $k_{t}=x_{t}$. Operating profits of an intermediate goods producer $\pi_{i, t}$ are thus given by $\pi_{i, t}=p_{i, t}\left(x_{i, t}\right) k_{i, t}-r_{t} k_{i, t}=\alpha B_{t}\left(H_{t}^{Y}\right)^{1-\alpha}\left(k_{i, t}\right)^{\alpha}-r_{t} k_{i, t}$ where $r_{t}$ denotes the interest rate that has to be paid for individual's savings. Solving the associated problem of profit maximization given demand (10) leads to the price of $p_{i, t}=p_{t}=r_{t} / \alpha$ for all $i=1, \ldots, A$ types of machines so that the machine-specific index can be dropped.

Free entry into capital goods production implies that in equilibrium operating profits are covering the fixed costs of production originating from purchasing a patent. In slight deviation from the original setup and inspired by Aghion and Howitt (2009, Chapter 4) we assume that a patent holds for one period (i.e. one generation) and that afterwards, in any future period $t+1$ the monopoly right is sold at price $\pi_{t+1}$ to someone chosen at random from the currently active generation. The revenue is spent unproductively on public consumption. This simplification helps to avoid intertemporal (dynastic) problems of patent holding and patent pricing while keeping the basic incentive to create new knowledge intact. Summarizing, free entry implies $\pi_{i, t}=\pi_{t}=p_{t}^{A}$ where $p_{t}^{A}$ is the price of a patent (blueprint).

Because capital goods are sold at the same price and demanded at equal quantities, $x_{i, t}=x_{t}$ aggregate capital is given by $K_{t}=A_{t} x_{t}$. Inserting this information into the production of final goods, equation (8) simplifies to

$$
Y_{t}=B_{t} A_{t}^{1-\alpha}\left(H_{t}^{Y}\right)^{1-\alpha} K_{t}^{\alpha}
$$

3.6. Knowledge Production. We consider two forces driving the evolution of knowledge and aggregate productivity. First, $A_{t}$ is driven by the development of new products through market R\&D and, second, $B_{t}$ rises through learning-by-doing. Standard R\&D-based growth theory usually neglects learning-by-doing because it focusses solely on modern economies. Here, within a unified growth setting, which encompasses centuries or millennia of economic development, we need a force to drive productivity growth before the onset of market R\&D. In line with Kremer (1993), Galor and Weil (2000), and Galor (2005) we assume that these learning-by-doing activities depend positively on the scale of the economy measured by population size, $\left(B_{t+1}-B_{t}\right) / B_{t}=\tilde{g}\left(L_{t}\right), \partial \tilde{g} / \partial L \geq 0$, $\partial^{2} \tilde{g} / \partial L^{2} \leq 0$. The learning-by-doing mechanism is appropriate to investigate technological and economic development for most of human history because technological advances were not (much) brought forward by formally trained scientists before the industrial revolution (Mokyr, 2002). 
In an equilibrium with $\mathrm{R} \& \mathrm{D}$, that is with $H_{t}^{A}>0$, competitive $\mathrm{R} \& \mathrm{D}$-firms employ $H_{t}^{A}$ researchers to develop $A_{t+1}-A_{t}$ new blueprints and sell them at price $p_{t}^{A}$. Facing research productivity $\delta_{t}$ output is given by

$$
A_{t+1}-A_{t}=\delta_{t} H_{t}^{A}
$$

The productivity of research $\delta_{t}$ is given to the single firm but depends, on the aggregate level, positively on the number of already existing ideas $(0<\phi<1$, standing-on-shoulders effect) and possibly negatively on the size of the workforce $\left(0 \leq \nu<1\right.$, stepping-on-toes), $\delta_{t}=\bar{\delta} A_{t}^{\phi} L_{t}^{-\nu}$, where $\bar{\delta}>0$ is a scaling parameter. Note that the negative stepping-on-toes effect increases in physical labor $L_{t}$ not in aggregate human capital $H_{t}$. The reason is that there cannot be stepping-on-toes with respect to individual $h_{t}$ because the same person will not develop the same idea twice.

Maximization of profits $p_{t}^{A} \delta_{t} H_{t}^{A}-w_{t} H_{t}^{A}$ implies that wages are given by $w_{t}=\delta_{t} p_{t}^{A}$ at an interior solution with positive R\&D. Labor demand in research adds up with labor demand in final goods production to aggregate labor demand

$$
H_{t}=H_{t}^{A}+H_{t}^{Y}
$$

In equilibrium with $\mathrm{R} \& \mathrm{D}$, wages in goods production and in $\mathrm{R} \& \mathrm{D}$ equalize such that $\delta_{t} p_{t}^{A}=$ $(1-\alpha) Y_{t} / H_{t}^{Y}$. By inserting demand (10) into the goods price $p_{t}=r_{t} / \alpha$ and the result into profits, the free entry condition can be written as $p_{t}^{A}=\pi_{t}=\alpha(1-\alpha) Y_{t} / A_{t}$. Next, use these two equations for $p_{t}^{A}$ to eliminate the price of blueprints and to arrive at labor demand $H_{t}^{Y}=A_{t} /\left(\alpha \delta_{t}\right)$ and thus $H_{t}^{A}=H_{t}-A_{t} /\left(\alpha \delta_{t}\right)$. Inserting employment of researchers $H_{t}^{A}$ from (13), the definition of R\&D productivity $\delta_{t}$, and the definition of aggregate human capital into research output (12) provides the evolution of R\&D specific knowledge as a function of human capital per person $h_{t}$, and the size of the workforce $L_{t}$,

$$
A_{t+1}=\bar{\delta} A_{t}^{\phi} h_{t} L_{t}^{1-\nu}-\frac{1-\alpha}{\alpha} A_{t}
$$

which constitutes the human-capital augmented Romer-Jones result.

In an equilibrium without $\mathrm{R} \& \mathrm{D}$ the non-negativity constraint for employment in $\mathrm{R} \& \mathrm{D}, H_{t}^{A} \geq 0$, is binding, that is $H_{t} \leq A_{t} /(\alpha \bar{\delta})$. If the aggregate stock of human capital is sufficiently low, all labor supply is absorbed by the final goods sector and $R \& D$ as a market activity does not take place. If there is no $\mathrm{R} \& \mathrm{D}$, the productivity parameter $A_{t}=A_{0}$ and all workforce is in the final goods sector, $H_{t}=H_{t}^{Y}$. 
Note that market $\mathrm{R} \& \mathrm{D}$ sets in endogenously when aggregate human capital, $H_{t}$, becomes sufficiently abundant. Since $H_{t}=h_{t} L_{t}$, this allows for two potential mechanisms to trigger R\&D. In the first case $R \& D$ sets in before the fertility transition. In this case aggregate human capital is getting sufficiently large for R\&D through the increasing workforce $L_{t}$. In the second case R\&D sets in after the fertility transition, which means that it is triggered by the increasing human capital endowment per worker $h_{t}$. In the calibration below we focus on the G-7, i.e. a case in which patented research (i.e. market $R \& D)$ sets in before the fertility transition. The implied rising wages subsequently initiate the onset of mass education and a fertility transition. The model, however, is general enough to allow as well a calibration for the reverse timing of events. This could be applied to a different set of countries, for example, some of today's LDCs, in which the fertility transition sets in before the onset of market R\&D.

Turning towards the physical factors of production, population $N_{t}$ grows at the fertility rate,

$$
N_{t+1}=n_{t} N_{t}
$$

Taking child rearing time into account the size of the workforce is given by $L_{t}=\left(1-\tau n_{t}\right) N_{t}$. Physical capital is assumed to depreciate fully within a generation such that next period's capital stock consists of this period's savings, $K_{t+1}=s_{t} N_{t}$. Inserting the solution for savings (2) and wages from (9) and (11) and substituting $H_{t}^{Y}=A_{t} /(\alpha \bar{\delta})$ provides the evolution of aggregate capital,

$$
K_{t+1}=\tilde{B}_{t} K_{t}^{\alpha} A_{t}^{1-\alpha-\alpha(1-\phi)} h_{t} L_{t}^{1-\nu \alpha}
$$

with $\left.\tilde{B}_{t} \equiv B_{t} \beta(1-\alpha)(\alpha \bar{\delta})^{\alpha} / / 1-\tau n_{t}\right) /(1+\beta+\eta)$. This completes the model.

In the following we show that the model explains why lower fertility is associated with higher growth of TFP and income in modern economies along the steady state as well as a phenomenon of adjustment dynamics. In the next section we focus on the steady state (i.e. the balanced growth path) and its comparative statics. This allows us to prove the results analytically and to fully understand the underlying mechanisms. Section 5 then investigates adjustment dynamics for a numerically calibrated model. Compared to steady-state analysis, the investigation of adjustment dynamics has the disadvantage that results can no longer be proven analytically but it allows us to explore the historical take-off period to growth and to project the future in the medium-run. 


\section{The Balanced Growth Path and its Comparative Statics}

4.1. TFP Growth and Population Growth. A balanced growth path (BGP) is defined as a state of the economy at which growth rates do not change. Constant population growth means that population $L_{t}$ and workforce $N_{t}$ grow at the same gross rate $n_{t}$, which is constant (above, below, or at replacement level) along the BGP . For any variable $x$, the growth rate is denoted by $g_{x, t}=\left(x_{t+1}-x_{t}\right) / x_{t}$ and its rate of change by $\hat{g}_{x, t} \equiv\left(g_{x_{t+1}}-g_{x_{t}}\right) / g_{x_{t}}$. Balanced growth thus requires $\hat{g}_{x}=0$ for $x=A, K, h, L$. We denote a growth rate of $x$ along the BGP by $g_{x}$, i.e. by omitting the time index. Naturally, because of decreasing returns of learning-by-doing, asymptotically $g_{B}=0$. Along the asymptotically attained BGP productivity growth is solely driven by market R\&D. For $\hat{g}_{A}=0$ we obtain from (14) that along the BGP

$$
\left(\frac{A_{t+1}}{A_{t}}\right)^{1-\phi}=\left(\frac{h_{t+1}}{h_{t}}\right)\left(\frac{L_{t+1}}{L_{t}}\right)^{1-\nu}=\left(\frac{h_{t+1}}{h_{t}}\right) n_{t}^{1-\nu}
$$

Superficial inspection thus seemingly suggests that TFP growth and population growth are positively correlated. This is the macro-view of the economy, which disregards interaction on the micro-level and seemingly predicts - in line with the available literature on R\&D-based growth - that higher population growth leads to higher productivity growth.

Assume for a moment, that there is no fertility transition and no (mass) education, for example, because schooling is ineffective, $A_{E}=0$. Inserting $h_{t+1} / h_{t}=1$ into (17) we get productivity growth

$$
g_{A}=n_{t}^{\frac{1-\nu}{1-\phi}}-1
$$

From this result we could indeed conclude that there is a unique positive association between productivity growth and population growth. The model has collapsed to an overlapping generations version of the well-known semi-endogenous growth model (Jones, 1995). The problem is that, actually, there was a fertility transition. The results from the conventional R\&D-based literature are thus hard to conceptualize as a steady-state phenomenon. The conventional model seems more appropriate for the period between the first and second industrial revolution, i.e. as a description of the transitional period during which there was already market $R \& D$ but not yet (mass) education. In the present model, schooling is assumed to be effective, $A_{E}>0$, implying that rising wages endogenously generate the onset of mass education. A positive association between R\&D-based productivity growth and population growth is thus identified for a transitional period and not as a steady-state phenomenon. 
After the onset of the fertility transition, i.e. after labor income surpasses $z$ in (3) and (4), human capital and fertility are endogenous and inversely correlated via the quantity-quality trade-off. Along a balanced growth path with positive growth income $\left(w_{t} h_{t}\right)$ is perpetually growing and fertility and the growth rate of human capital are constants. Inserting $\underline{\mathrm{n}}$ and $\Delta_{h}$ from (5) and (7) into (17) provides the expression

$$
\left(\frac{A_{t+1}}{A_{t}}\right)^{1-\phi}=A_{E} \frac{\gamma \tau}{\eta-\gamma}\left(\frac{\eta-\gamma}{(1+\beta+\eta) \tau}\right)^{1-\nu} .
$$

Obviously, the most positive role that population growth could possibly play for TFP growth exists when there is no congestion in research, i.e. for $\nu=0$. In this case the expression simplifies further and the balanced growth rate of TFP and - after inserting (5) into (15) - the population growth rate is obtained as in (18).

$$
g_{A}=\left(\frac{\gamma A_{E}}{1+\beta+\eta}\right)^{1 /(1-\phi)}-1, \quad g_{L}=\frac{\eta-\gamma}{(1+\beta+\eta) \tau}-1
$$

Inspecting the growth rates shows that a higher weight of child quality in utility causes $g_{A}$ to rise and $g_{L}$ to fall. The opposite holds true for a decreasing weight of child quantity in utility. A proposition summarizes the main result of the paper.

Proposition 1. A higher weight on child quality $\gamma$ or a lower weight on child quantity $\eta$ implies a higher rate of TFP growth and a lower rate of population growth along the balanced growth path.

This means that for two otherwise identical economies TFP growth is higher in the economy in which parents put relatively less weight on child quantity, that is the one in which the fertility transition ends at a lower level of population growth. Congestion in research $(\nu>0)$ amplifies this result by reducing the role of $n_{t}$ in TFP growth. More importantly, note that the result is independent from the size of $n_{t}$. In particular, it holds also when population growth $g_{L}=n_{t}-1$ is negative.

For an intuition of the result recall the definition of aggregate human capital $H_{t}=h_{t} L_{t}$. Without congestion a positive effect of declining population on productivity requires that a higher preference for child quality exerts a stronger effect on human capital endowment per person of the next generation than on the number of persons such that $h_{t}$ grows more than $L_{t}$ falls. This is exactly what our model-parents provide. Inserting (5) and (7) into $H_{t+1} / H_{t}=n_{t} \cdot\left(h_{t+1} / h_{t}\right)$ we obtain the growth rate of aggregate human capital along the BGP, which depends positively on $\gamma$ (and negatively on 
$\eta)$

$$
g_{H}=\frac{\eta-\gamma}{(1+\beta+\eta) \tau} \cdot \frac{\gamma \tau A_{E}}{\eta-\gamma}-1=\frac{\gamma A_{E}}{1+\beta+\eta}-1 \quad \Rightarrow \quad \frac{\partial g_{H}}{\partial \gamma}=\frac{A_{E}}{1+\beta+\eta}>0
$$

The mechanism behind the result originates from the interaction in the budget constraint (and not from specifications of the utility function). To see this clearly consider a unit increase of $e_{t}$ in company with a unit reduction of $n_{t}$ such that total voluntary child expenditure $n_{t} e_{t}$ remains constant. This one-to-one quantity-quality substitution is not neutral. It sets free income $\tau w_{t} h_{t}$ because less time is needed for child rearing so that more time can be supplied on the labor market. The additionally earned income can be spent on current and future consumption and on further child expenditure $e_{t}$ implying that the negative effect from reduction of fertility is smaller than the positive effect on human capital such that $H_{t}=h_{t} n_{t}$ rises. Because the mechanism arises from the budget constraint, we are confident that the result holds also for more general forms of the utility function.

Turning towards the impact of time costs of children we see from (18) that a change of $\tau$ without congestion in R\&D affects population growth but not productivity growth. Intuitively, rising costs of children lead to lower fertility and higher voluntary expenditure per child. For aggregate human capital $H_{t}=h_{t} L_{t}$ the negative effect through lower fertility and the positive effect via higher human capital growth per capita are exactly leveling each other such that $H_{t+1} / H_{t}=\gamma A_{E} /(1+\beta+\eta)$ is independent from $\tau$ and thus $\partial g_{H} / \partial \tau=0$.

The mechanics behind the result originate again from the budget constraint, but this time logutility and its feature of balancing income and substitution effects plays a role as well. Higher child costs lead to lower child demand $n_{t}$ and lower available income $\left(1-\tau n_{t}\right) w_{t} h_{t}$. With unchanged preferences income and substitution effect are balancing each other such that total expenditure $n_{t} e_{t}$ remains constant. A utility function supporting a higher substitution effect would imply an overcompensating effect of human capital over fertility.

If there is congestion in $\mathrm{R} \& \mathrm{D}$, i.e. if $\nu>0$ in $\left(A_{t+1} / A_{t}\right)^{1-\phi}=n_{t}^{1-\nu}\left(h_{t+1} / h_{t}\right)$, then child rearing costs have an impact on productivity growth because the positive effect through rising human capital dominates the negative effect through falling fertility. This observation proves the following proposition.

Proposition 2. If there is congestion in RED (stepping on toes) then increasing time costs for rearing children leads to lower population growth and higher TFP growth along the balanced growth path. Without congestion in RED child time costs are neutral for productivity growth. 
4.2. Income Growth and Population Growth. In order to examine the rest of the model, we evaluate (16) along the balanced growth path (i.e. for $\left.\hat{g}_{K}=0\right)$ and substitute $\left(h_{t+1} / h_{t}\right)$ from $(17)$. This provides

$$
\left(\frac{K_{t+1}}{K_{t}}\right)=\left(\frac{A_{t+1}}{A_{t}}\right)^{2-\phi}\left(\frac{L_{t+1}}{L_{t}}\right)^{\nu} .
$$

Without congestion in $\mathrm{R} \& \mathrm{D}(\nu=0)$ the model predicts that growth of physical capital along the balanced growth path correlates positively with TFP growth but not with population growth. For $\phi \rightarrow 1$ the model predicts that the capital stock grows at the rate of TFP growth. Note the difference to neoclassical growth theory, which predicts that the capital stock grows at the rate of TFP growth plus the rate of population growth. With human capital and R\&D being endogenous, a positive association between capital growth and population growth emerges "only" when there is congestion in research.

Finally, substitute labor demand $H_{t}^{Y}=A_{t} /(\alpha \delta)$ into production (11) and take time-differences to get output growth $g_{Y t}=\left(1+g_{K t}\right)^{\alpha}\left(1+g_{A t}\right)^{(1-\alpha)(2-\phi)}\left(1+g_{L t}\right)^{\nu(1-\alpha)}-1$. Insert this information into growth of output per worker $y_{t}=Y_{t} / L_{t}$, i.e. into $\left(1+g_{y_{t}}\right)=\left(1+g_{Y t}\right) /\left(1+g_{L t}\right)$. In order to evaluate income per capita growth along the balanced growth path insert $g_{A}$ and $g_{K}$ from (17) and (19) to arrive at (20).

$$
1+g_{y}=\left(\frac{h_{t+1}}{h_{t}}\right)^{\frac{2-\phi}{1-\phi}} n_{t}^{\frac{1-\nu}{1-\phi}} .
$$

Superficial inspection suggests again a seemingly positive association between income growth $g_{y}$ and population growth (fertility). However, because education is effective $\left(A_{E}>0\right)$, increasing labor income triggers a fertility transition and a situation with $R \& D$ but without education is unsustainable in the long-run. Inserting $\underline{\mathrm{n}}$ and $\Delta_{h}$ from (5) and (7) into (20) provides (21).

$$
1+g_{y}=\left(\frac{\gamma \tau A_{e}}{\eta-\gamma}\right)^{\frac{2-\phi}{1-\phi}} \cdot\left(\frac{\eta-\gamma}{(1+\beta+\eta) \tau}\right)^{\frac{1-\nu}{1-\phi}}
$$

Taking the derivatives with respect to $\gamma$ and $\eta$ provides a result analogously to Proposition 1 .

Proposition 3. A higher weight on child quality in utility or a lower weight on child quantity implies a higher rate of growth of income per capita and a lower rate of population growth along the balanced growth path.

Furthermore, since $2-\phi>1-\nu$ : 
Proposition 4. Higher child-rearing costs $\tau$ imply a higher rate of growth of income per capita and a lower rate of population growth along the balanced growth path. Without congestion in R\&D child time costs are neutral for income growth.

It is instructive to compare R\&D effort along the BGP with the earlier R\&D-based growth models. Models of the first generation (Romer, 1990; Aghion and Howitt, 1992) predict constant TFP growth for a constant number of researchers. For this to be true the unpleasant knife-edge assumption $\phi=1$ has to hold. Models of the second generation (Jones, 1995, Segerstrom, 1998) predict based on $\phi<1$ that constant TFP growth is realized for a constant population share of researchers and positive population growth, implying the unpleasant result that constant economic growth requires a perpetually rising number of people employed in $R \& D$. The present theory reconciles the earlier theories. It abandons the knife-edge assumption but preserves the empirical relevant associations between research effort and TFP.

Proposition 5. Along the balanced growth path constant TFP growth is associated with a constant share of the population working in R\&D and constant R\&D expenditure share of GDP. These results hold true for $\phi<1$ irrespective of whether the number of people employed in RED is rising, constant, or declining. If the population stays constant, constant TFP growth implies a constant number of workers engaged in RED.

For a proof let the number of workers in goods production be denoted by $L_{t}^{Y}$. Begin with noting that the share of workers in goods production is given by $L_{t}^{Y} / L_{t}=\left(h_{t} L_{t}^{Y}\right)\left(h_{t} L_{t}\right) /=H_{t}^{Y} / H_{t}$. Insert $H_{t}^{Y}=A_{t} /\left(\alpha \delta H_{t}\right)$ and the definitions of $H_{t}$ and $\delta$ to get $L_{t}^{Y} / L_{t}=A_{t}^{1-\phi} /\left(\alpha \bar{\delta} h_{t} L_{t}^{1-\nu}\right)$. Conclude from (17) that numerator and denominator of this expression are growing at equal rates at the steady state. Thus $L_{t}^{Y} / L_{t}$ stays constant implying a constant population share in R\&D.

For the second part of the proof, R\&D expenditure is given by $\rho_{t}=w_{t} H_{t}^{A}$ and its share of GDP by $\rho_{t} / Y_{t}=w_{t} H_{t}^{A} / Y_{t}$. Insert wages from (9) to get $\rho_{t} / Y_{t}=(1-\alpha) H_{t}^{A} / H_{t}^{Y}$, which is constant since $H_{t}^{Y} / H_{t}$ and $H_{t}^{A} / H_{t}$ are constant along the steady state.

\section{Adjustment Dynamics: The Take-off, the Productivity Reversal, and the}

\section{Future of R\&D-BASED GROWTH}

In this section we investigate long-run adjustment dynamics towards balanced growth. We explore the take-off of $R \& D$-based growth, the take-off of mass education, and the productivity 
reversal. Initially, in the pre-modern era, both non-negativity constraints, $w_{t} h_{t}-z \geq 0$ and $H_{t}=L_{t} h_{t}-A_{t} /(\alpha \delta) \geq 0$ are binding with equality implying that there is neither market $\mathrm{R} \& \mathrm{D}$ nor mass education. Growth is solely driven by learning-by-doing as in Kremer (1993) and in Galor (2005). We calibrate the model such that market R\&D sets in first (the first Industrial Revolution) and triggers, later on, the onset of (mass) education. Such a scenario seems not only to be in line with the historical evolution of England and Western Europe (Galor, 2005) it also allows us also to investigate a transitional period in which $\mathrm{R} \& \mathrm{D}$ growth is fueled solely by population growth; i.e. by the mechanism that is assumed to drive growth at the steady state according to the semi-endogenous R\&D-based growth literature.

In a unified growth context, however, a period of R\&D-based growth without education constitutes only a transitory phase and not a steady-state phenomenon. Eventually, rising income triggers education, and the demographic transition sets in. With rising human capital and declining fertility the economy converges towards the balanced growth path. While standard R\&D-based growth theory would predict that economic growth declines with ongoing demographic transition because of declining population growth, the quality-quantity substitution present model allows economic growth to increase with declining population growth.

Advocates of R\&D-based growth emphasize that - because of knowledge spillovers - the country is a misleading unit of analysis. We try to accommodate this notion by calibrating the model to an average G-7, using population weights. This means that the US plays a relatively big role in the 20th century and that the results are robust against reducing or increasing the group of countries by one country or another. The G-7 approximates a group of countries which can be thought of as producing leading-edge $R \& D$-based research and which thereby exchange knowledge with each other.

For the benchmark run we set the parameters $\beta, \gamma$, and $\eta$ such that the model produces a savings rate of 0.2 along the BGP, a total fertility rate (TFR) of 3.8 children per couple $(n=1.9)$ before the demographic transition sets in, and a TFR of 1.78 at the end of the demographic transition. We thus assume that average fertility stays at the current level forever. Later on, we take up the UN projection about future fertility rates, including scenarios with fast and slow return of fertility to replacement level or above. The best match with the historical path of education is obtained when rearing a child takes away 8.8 percent of adult time $(\tau=0.088)$. This leads to the estimate $\beta=0.31$, 
$\gamma=0.14, \eta=0.26$. After running the simulation we convert generational into annual data for better comparison with the actual historical time series by assuming that a generation takes 30 years.

We set $\alpha=0.4$ and adjust $\phi=0.3, \nu=0.8$, and $A_{E}=11$ to get the best fit of the empirical time series of fertility, income, and TFP growth during the late 20th century. We assume a learning-bydoing function $g_{B}=\mu L^{\lambda}$, set $\lambda=0.05$ and $\mu=0.0005$ implying that income per worker grew at 0.5 percent per annum from 1600 to 1760 (in line with Broadberry et al., 2010). We set the remaining parameters $\bar{\delta}$, and $\bar{e}$ to get the speed of the fertility transition and the chronological distance between the onset of R\&D-based growth and the fertility transition about right. This provides $\bar{\delta}=1.72$ and $\bar{e}=0.09$. We set $A_{0}=0.8$ and $B_{0}=1$. The initial value for population size and physical capital depend, naturally, on the initial time when we start the economy. We set the initial time to the year 1000 implying $K_{0}=0.00011$ and $L_{0}=0.137$.

Solid lines in Figure 3 show the implied adjustment dynamics. The model generates the onset of R\&D-based growth in 1760 (shown in the fourth panel from above). The implied path of growth of R\&D output $g_{A}$ is compared with the smoothed time series of average TFP growth in the G-7 . The model predicts correctly that TFP growth is much higher during the 20th century than in the centuries before but it overestimates the growth of TFP by about a factor of 2 . One reason for this is that actual TFP is computed as a residual and depends on several confounding terms not just the growth rate of ideas. Another possibility is to compare $g_{A}$ with the average annual growth rate of patent applications in the G-7, which was 1.2 percent in the 1960-1980 period and 2.8 percent in the 1980-2000 period. The predicted growth rate of ideas captures this trend correctly but now it mildly underestimated the actual time series. One reason for this could be that the actual evolution of patent applications includes the rise of strategic patenting, a phenomenon which is not included in our model.

The first panel in Figure 3 shows the evolution of fertility. In order to compare with the real data we double the number of children predicted by our unisex model to get the number of children per couple of adults, which we depict jointly with the average TFR in the G-7 countries. The green (dashed-dotted) line shows the actual data and the red (dashed) line shows the smoothed long-run trend that appears after applying the Hodrick-Prescott filter. The trend eliminates the baby boom after World War II. The onset of the fertility decline is predicted by the model for the year 1910, which coincides with the actual onset of the fertility decline in England and captures the average onset of the decline in the G-7 reasonably well (see Fn. 8). The model gets the speed of the fertility 
Figure 3: The Take-Off to Growth and Long-Run Adjustment Dynamics
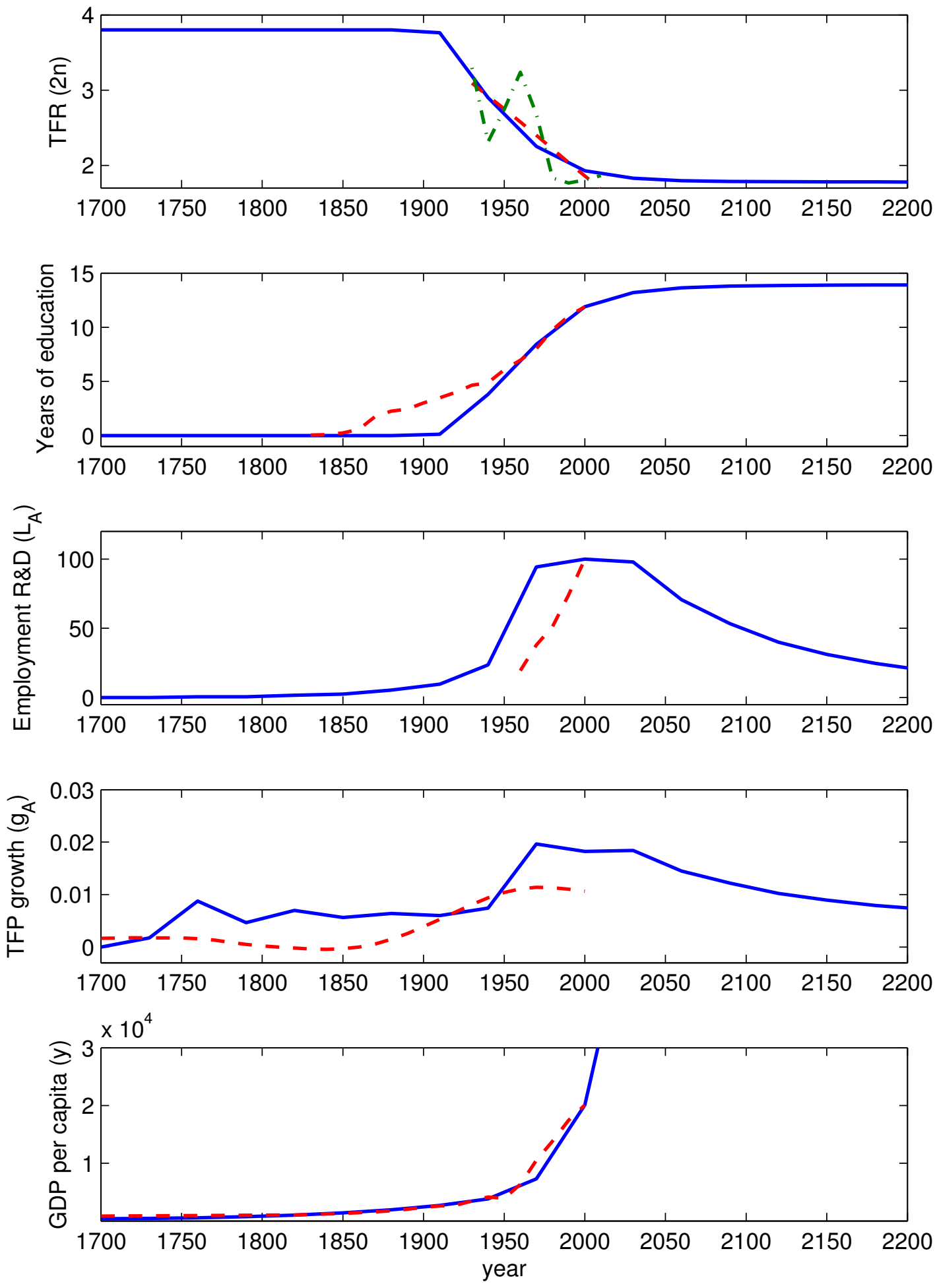

Solid lines: calibrated economy. Dashed lines: data for G-7 (country time series weighted by population size). TFP time series smoothed with Hodrick-Prescott filter (smoothing parameter 100). TFR: red (dashed) line: smoothed data (HP 100); green (dash-dotted) line: raw data. See text for details. 
transition (reflected by the slope of the time series) about right, implying that it correctly predicts the actual TFR in 2010. In the benchmark scenario we assume that fertility follows this trend and levels off at a TFR of 1.78 at the end of the century. We discuss alternative scenarios below.

In order to compare the model predictions with the actual data we convert schooling expenditure, measured relative to labor income, $e /(w h)$, into years of education. We normalize such that the schooling effort in the year 2000 corresponds with 11.9 years of education, the observed G-7 average in the same year. The onset of mass education, according to our model, is happens jointly with the fertility transition, a feature that is shared with the standard theory of unified growth (Galor, 2005). With respect to the G-7 this means that education is predicted to start rising about 2 generations too late, as shown in the second panel from above. For the purpose of this paper, however, the second half of the 20th century is more interesting, because then (in 1970) fertility crosses the replacement level and the population starts to decline. For the 1960-2000 period the model prediction virtually coincides with the G-7 data. The model predicts that the huge growth of education is a unique phenomenon of the 20th century. For the 21st century and after, education effort (years of schooling) is predicted to level off. This implies that the growth rate of human capital converges from above towards a small but positive rate (0.3 percent).

The third panel in Figure 3 shows employment in research, measured as the number of researchers $L_{A}=H_{A} L / H$. In order to compare with the G-7 data we normalize the number of researchers in the year 2000 to 100 . The model predicts a very mild increase of $L_{A}$ in 1760 , a somewhat stronger increase in 1850, and a huge increase for the second half of the 20th century. The dashed trajectory shows the number of scientists and engineers in the G-7. Compared with the data, the model gets the growth of employment in R\&D (represented by the slope of the curve) about right. The steep increase of $R \& D$, however, happens about a decade too early. The increase of R\&D-employment is predicted to level off in the late 20th century but not to fall until about the second half of the 21st century. It is thus possible, as an off-steady-state phenomenon, that the population declines (since 1970 according to the model) but the scale of $\mathrm{R} \& \mathrm{D}$ employment is not declining. As a consequence the model predicts almost constant TFP growth for the first half of the 21th century.

The bottom panel in Figure 3 shows the evolution of income per capita. Income starts to increase somewhat with the onset of R\&D-based growth and then really takes off with increasing education. The model matches the evolution of income per capita for the average G-7 reasonably well. 


\section{The Future of R\&D-Based Growth}

In order to asses the future growth perspectives in the medium-run we re-calibrate the model to capture the UN (2011) fertility projections for the G-7 in the 21st century. For that purpose we introduce two alternative ways of parameter change which are thought to capture the idea that fertility change is elicited by changing policy or changing attitudes towards children.

Turning first towards policy, we assume that child rearing costs $\tau$ are function of calender time $t$ after the year 2000. Given a length of a generation of 30 years, the policy starts to change fertility behavior for the first time in 2030 .

$$
\tau(t)=\tau_{\infty}+\rho^{t-2030} \cdot\left[\tau(2030)-\tau_{\infty}\right]
$$

We calibrate $\tau_{\infty}$ such that two times the associated fertility rate $n\left(\tau_{\infty}\right)$, according to (4), coincides with the TFR that the UN assumes to hold in the long-run. In its medium scenario the UN assumes that the TFR converges towards 2.1 , implying $\tau_{\infty}=0.746$. The parameter $\rho$ controls the speed of convergence and we set $\rho=0.3$ to capture the UN projection.

The blue (solid) line in Figure 4 shows the implied evolution of the TFR and productivity growth. With higher steady-state fertility, productivity growth in the long-run is lower than in our benchmark case of Figure 3, in line with the propositions proved in the theory section. We observe furthermore a quite drastic decline of productivity in the mid 21st century, compared with a more gradual convergence in the benchmark case. Red (dashed) lines in Figure 4 show the model's prediction under the UN high-fertility projection. This means that $\tau_{\infty}$ is adjusted such that $2 n$ converge to 2.5 during the 21st century. The predicted downfall of productivity growth gets now even larger. The green (dash-dotted) lines show the outcome under the UN low-fertility projection, assuming that $2 n$ converge towards 1.5. In that case the model predicts convergence towards a higher long-run level of productivity growth and trendless high growth for the almost the whole 21st century.

Adjusting fertility via child-rearing costs implies a relatively benign view on population growth. Negative effects of population growth on income growth occur solely through congestion in R\&D (recall Proposition 2 and 4). Alternatively, we next calibrate the UN fertility projections through adjustment of attitudes towards children. Specifically we adjust $\eta$, the weight of children in utility. We calibrate $\eta_{\infty}$ to match the UN projections for the long-run and compute convergence as $\eta(t)=$ $\eta_{\infty}+\rho^{t-2030} \cdot\left[\eta(2030)-\eta_{\infty}\right]$. Compared to adjustment via $\tau$, a high fertility projection for the 
Figure 4: UN Population Projections and R\&D-based Productivity Growth ( $\tau$-scenario)
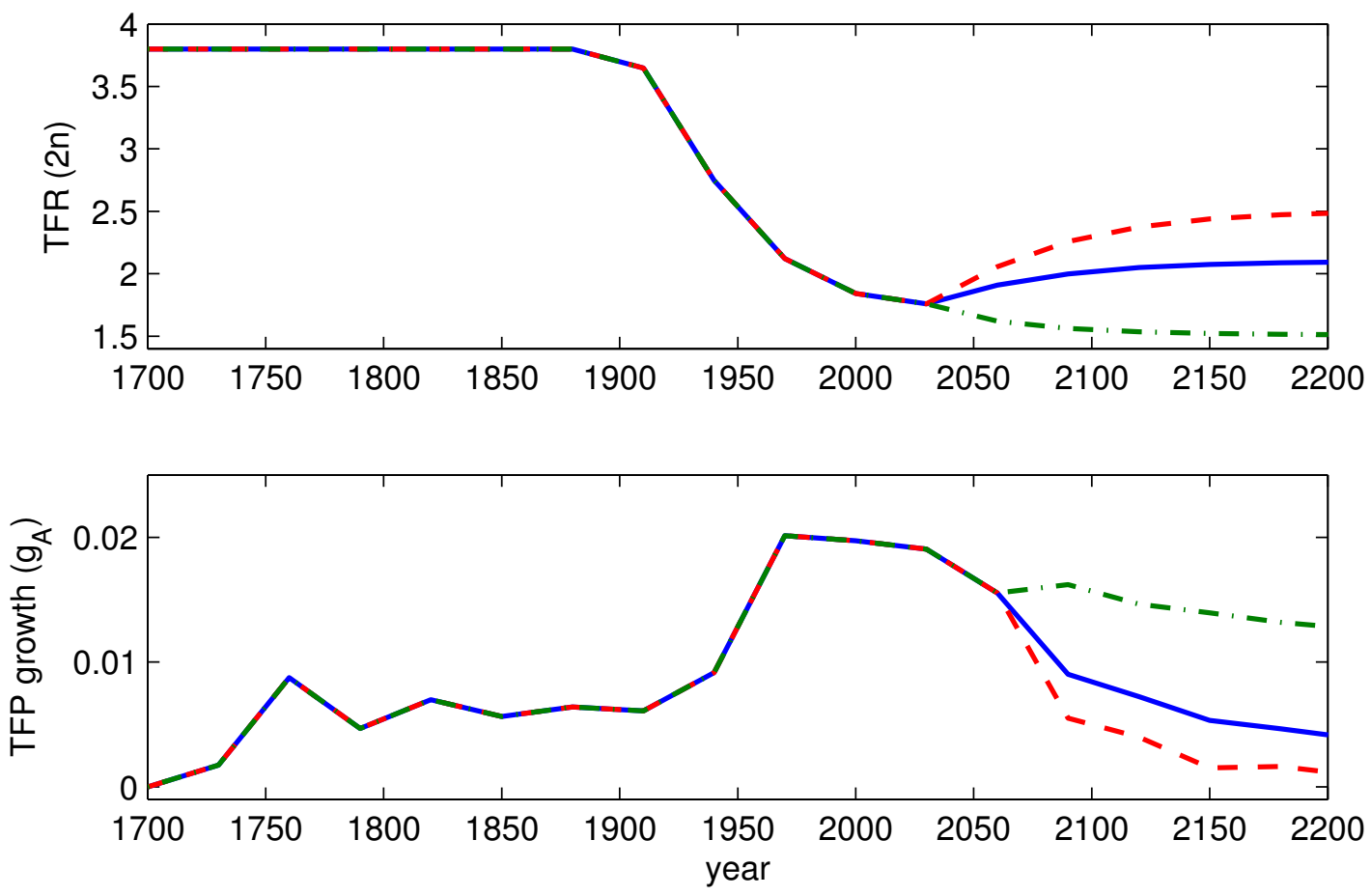

Economy calibrated as in Figure 3.Afer the year $2000 \tau$ is adjusted to match the UN TFR projections. Solid (blue) lines: UN-medium; dashed (red) lines: UN-high, dashed-dotted (green) lines: UN-low.

future implies a further negative effect because the child quantity-quality substitution is not neutral to aggregate human capital (recall Proposition 1 and 3).

Figure 5 shows the predictions by the model. In the medium TFR scenario (blue-solid lines), productivity is now predicted to decline faster during the late 21st century, compared to the $\tau-$ scenario. The reason is, as explained in the theory section, that higher fertility requires more child rearing time and thus a sacrifice in parental labor supply. Less labor supply and less labor income feeds back negatively on education spending, such that aggregate human capital declines. In case of the UN high-fertility projection (red-dashed lines) the growth rate of human capital and thus of productivity declines to virtually zero in the long-run. On the other hand, the prediction for long-run growth under the UN low-fertility projection (green-dash-dotted lines) are very promising. The model predicts high and virtually trendless growth throughout the 21st and 22nd century.

\section{Conclusion}

In this paper we have integrated R\&D-based innovations into a unified growth framework. We have shown how the consideration of an endogenous, microfounded evolution of fertility and education 
Figure 5: UN Population Projections and R\&D-based Productivity Growth ( $\eta$-scenario)
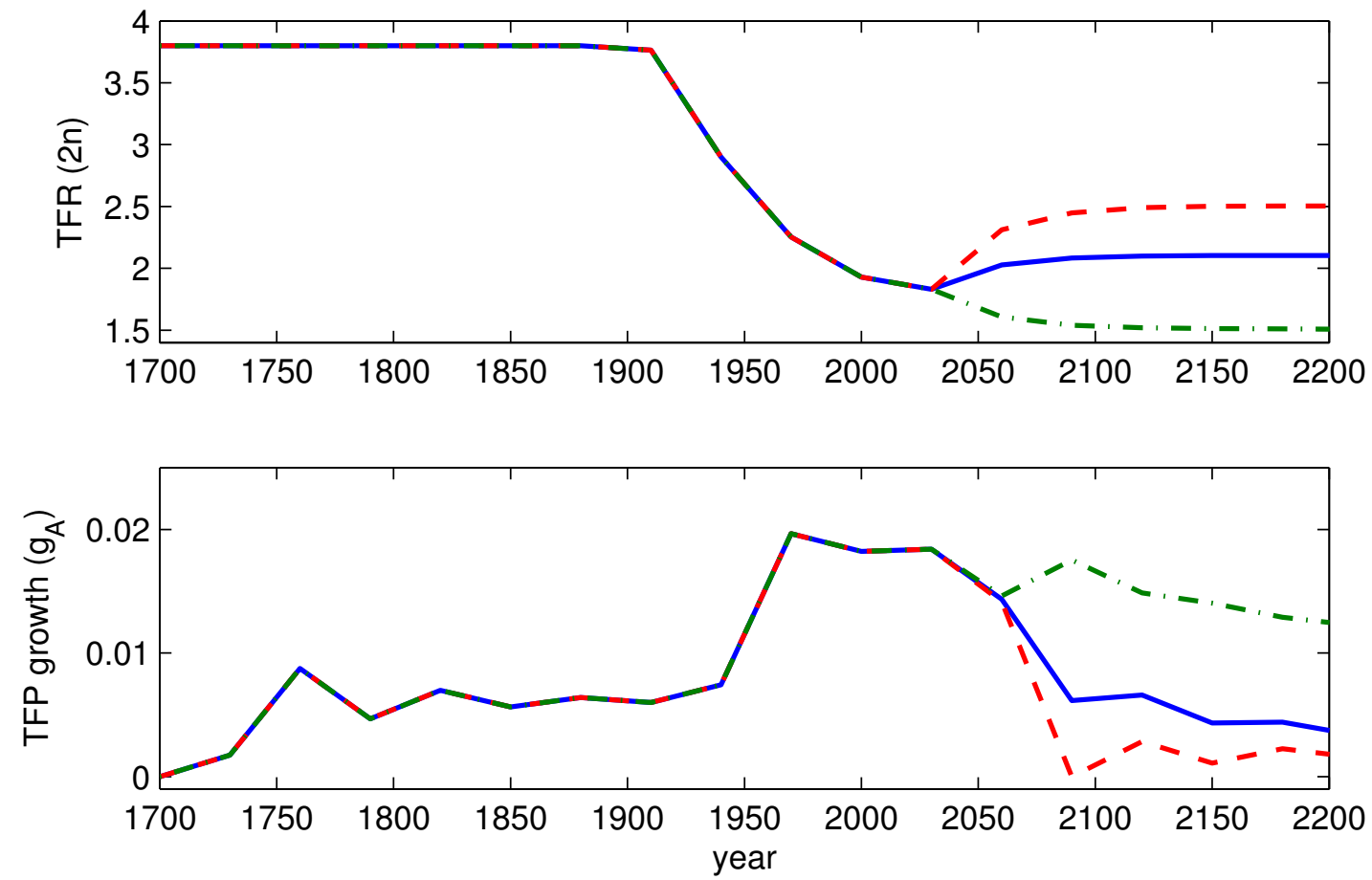

Economy calibrated as in Figure 3. After the year 2000 the parameter $\eta$ is adjusted to match the UN TFR projections. Solid (blue) lines: UN-medium; dashed (red) lines: UN-high, dashed-dotted (green) lines: UN-low.

modifies some central findings of the earlier R\&D-driven growth theory. While earlier models (in the spirit of Romer 1990 or Jones 1995) predicted that population growth is positively associated with economic growth, or even - in the Jones case - essential for having economic growth at all, our micro-founded theory predicts that the erstwhile positive association between population growth and productivity growth turns negative in the 20th century. The modified R\&D-based growth theory is thus less easily refuted by the available data for the 20th century.

Since we have maintained all central elements about the firms' side from R\&D-based growth theory it is clear that the new results originate from household behavior. The basic mechanism is generated by the interaction of child quality and quantity in the households' budget constraint and is observed independently from the specification of preferences, which makes us confident that our results are robust against a sophistication of the households' utility function.

Specifically, a substitution of child quantity $n$ by child quality (i.e. expenditure on education) $e$ that keeps total child expenditure $e \cdot n$ constant sets free parental time, which can be used to earn extra income. The additional income is partly spent on education such that overall child expenditure rises more strongly than child quantity falls. At the macro side of the economy this trade-off means 
that human capital per person $h$ increases more strongly than the number of persons $L$ falls such that total available human capital $h \cdot L$ increases. Given that human capital is the driving force in R\&D this entails higher R\&D output and higher R\&D-based growth.

We have calibrated the model for an average G-7 country and shown that the negative association between population growth and productivity growth is not only observable along the balanced growth path but also during the adjustment phase in the 20th century. The unified growth model has also produced novel insights about the timing of the onset of mass education and R\&D-based growth. It is capable of explaining how a first Industrial Revolution brought forward by tinkerers initiated mass education and a second Industrial Revolution, after which R\&D is produced by formally trained scientists. These details about the timing of long-run growth cannot be explained by the so far available growth theories because they neglect either R\&D-based growth (unified growth theory) or the micro-foundation of fertility and human capital accumulation (conventional R\&D-based growth theory).

Taking the quality-quantity trade-off into account allowed us to draw a much less grim conclusion about economic growth in the near future than suggested by the conventional R\&D-based growth literature. Our brighter assessment of the future does not depend on the assumption of constant returns in education. To see this recall that the model predicts a constant expenditure share of education (constant years of schooling) along the balanced growth path. It could thus be easily generalized towards decreasing returns at the individual level without implications for the results. The crucial ingredient enabling perpetual growth is the linear intergenerational transmission of human capital, i.e. the assumption that the current generation is capable to transport its knowledge times a multiplier larger than one to the next generation. While it is impossible to say whether such a process of knowledge transmission can be sustained forever, it is in any case easier conceivable than a perpetually growing population. Human capital is a metaphysical entity measured in valueunits whereas population is a physical entity bounded by physical constraints as, for example, space on earth. To see the intergenerational multiplier of the value of knowledge compare, for example, the value of knowledge acquired by a university study of medical science now and 100 years ago. An plausible extension of the model could take into account that the efficiency of the education technology $A_{E}$ is also time depending and positively influenced by the currently available productive knowledge $A_{t}$ (e.g. computer, multimedia, the internet). 
Instead of venturing forth into the domain of speculation about the distant future of humanity we would like to emphasize that our model is a metaphor to explain economic growth in the past, the present, and the near future (say within the limit of UN fertility projections). In the recent past, we observed high TFP growth in line with high growth of human capital and low and increasingly negative population growth, and we expect these trends to continue for a while. In this respect the main message delivered by the model is an optimistic one: the fact that fertility is below replacement level and population is declining is less threatening than suggested by conventional R\&D-based growth theory.

In the very long-run it is likely that fertility below replacement level and negative population growth run against physical and economic limits. This insight could have been another reason why the UN recently reconsidered its 2008 projections; assuming now adjustment to replacement level from below at the end of the 21. century (see also Myrskyla et al., 2009). With respect to growth of TFP and income per capita, our calibration for the G-7 suggests, that a slow return of fertility to replacement level is more desirable than a quick one. A slower return to replacement level allows for a stronger quantity-quality trade off and thus a higher rate of growth of aggregate human capital and R\&D-based growth through the transition period.

The model has been calibrated to accommodate the UN fertility projections by adjusting either child rearing costs or preferences. Alternatively, Strulik and Weisdorf (2008) have developed a unified growth model of a two-final-goods economy, which endogenously and independently from child costs and preferences produces convergence towards a stationary population in the very longrun and which predicts undershooting and negative population growth during the 21 st century as a transitional phenomenon. Combining these ideas with the present work is a challenging task for the future. 


\section{DAta Appendix}

List of Countries for Table 1: Algeria, Argentina, Australia, Austria, Belgium, Bolivia, Brazil, Bulgaria, Canada, Chile, China, Colombia, Costa Rica, Cyprus, Denmark, Dominican Republic, Ecuador, Egypt, El Salvador, Ethiopia, Finland, France, Greece, Guatemala, Guyana, Honduras, Hungary, India, Indonesia, Iran, Iraq, Ireland, Israel, Italy, Jamaica, Japan, Mexico, Morocco, Netherlands, New Zealand, Nicaragua, Nigeria, Norway, Pakistan, Panama, Paraguay, Philippines, Poland, Portugal, Romania, South Africa, South Korea, Spain, Sri Lanka, Sweden, Switzerland, Syria, Thailand, Tunisia, Turkey, UK, Uruguay, USA, Venezuela, Zaire, Zambia, Zimbabwe.

Data sources and construction of aggregated historical time series. We focus on the following countries (G-7): Canada, France, Germany, Italy, Japan, United Kingdom and United States. The data set spans from 1650 to 2000 and was constructed as a population-weighted average of the individual countries' time series. In so doing we relied on the following sources:

(1) From 1650 until 2000 we used per capita GDP and population size obtained from Angus Maddison's website at http://www.ggdc.net/MADDISON/oriindex.htm, see also Maddison (2001) for a detailed description.

(2) Data on TFP growth rates for the United Kingdom from 1650 to 2000 are from Madsen (2010), TFP growth rates for the United States between 1870 and 2000 are from Gordon (1999), and TFP growth rates for Canada, France, Germany, Italy and Japan are from Baier et al. (2006). For Canada the series covered the years 1880 to 2000, for France the years 1860 to 2000, for Germany the years 1890 to 2000, for Italy the years 1870 to 2000 and for Japan the years 1900 to 2000.

(3) Years of schooling data are from Baier et al. (2006). The corresponding series were available from 1830 to 2000 for the United Kingdom, from 1850 to 2000 for France, from 1860 to 2000 for Italy, from 1870 to 2000 for Canada and the United States and from 1890 to 2000 for Japan.

(4) The number of patent applications (of residents) between 1960 and 2000 are from the World Development Indicators Database (World Bank, 2012). The data is available at http:// databank . worldbank . org/ddp/home. do?Step=12\&id=4\&CNO=2.

(5) Fertility projections until 2100 were obtained from the United Nation's Population Division (United Nations, 2011). The data is available at http://esa. un.org/unpd/wpp/index.htm.

(6) As another robustness check we included the total fertility rates of the Human Fertility Database (2012). The data is available at http://www.humanfertility.org/cgi-bin/main. php. 


\section{References}

Aghion, P. and P. Howitt, 1992, A model of growth through creative destruction, Econometrica 60, $323-702$.

Aghion, P. and P. Howitt, 2009, The Economics of Growth, MIT Press, Cambridge, MA.

Ahituv, A., 2001, Be fruitful or multiply: On the interplay between fertility and economic development, Journal of Population Economics 14, 51-71.

Andreoni, J., 1989, Giving with impure altruism: Applications to charity and Ricardian equivalence, Journal of Political Economy 97, 1447-1458.

Ashraf, Q. and Galor, O., 2011, Dynamics and stagnation in the Malthusian epoch, American Economic Review 101, 2003-2041.

Baier, S.L., P.G. Dwyer Jr., and R. Tamura, 2006, How Important Are Capital and Total Factor Productivity for Economic Growth? Economic Inquiry 44, 23-49.

Becker, G.S., 1960, An economic analysis of fertility, in: National Bureau of Economic Research (ed), Demographic and Economic Change in Developed Countries, Princeton University Press, Princeton, 209-231.

Becker, G.S. and Lewis, H.G., 1973, On the interaction between the quantity and quality of children, Journal of Political Economy, 81, S279-S288.

Becker, G., Murphy. K., and Tamura, R., 1990, Human capital, fertility and growth. Journal of Political Economy, 98, S12-37.

Becker, S.O. and Cinnirella, F. and Woessmann, L., 2010, The trade-off between fertility and education: evidence from before the demographic transition, Journal of Economic Growth 15, 177-204.

Bernanke, B.S. and Gürkaynak, R.S., 2001, Is growth exogenous? Taking Mankiw, Romer, and Weil seriously, NBER macroeconomics annual 16, 11-57.

Bongaarts, J., 2001, Fertility and reproductive preferences in post-transitional societies, Population and Development Review 27, 260-281.

Bottazi, L. and G. Peri, 2003, Innovation, demand, and knowledge spillovers: Evidence form European patent data, European Economic Review 47, 687-710.

Brander, J.A., and S. Dowrick, 1994, The Role of Fertility and Population in Economic Growth, Journal of Population Economics 7, 1-25.

Broadberry, S., Campbell, B., Klein, A., Overton, M., and van Leuwwen, B., 2010, British Economic Growth 1270-1870, Discussion Paper, University of Warwick.

Connolly, M. and Peretto, P.F., 2003, Industry and the family: two engines of growth, Journal of Economic Growth 8, 115-148.

Dalgaard, C.-J. and Kreiner, C.T.,, 2001, Is declining productivity inevitable?, Journal of Economic Growth 6, 187-203. 
De La Croix, D. and Doepke, M., 2003, Inequality and growth: why differential fertility matters, American Economic Review 93, 1091-1113,

De La Croix, D. and Doepke, M., 2004, Public versus private education when differential fertility matters Journal of Development Economics 73, 607-629.

Dinopoulos, E. and P. Thompson, 1998, Schumpeterian growth without scale effects, Journal of Economic Growth 3, 313-335.

Funke, M. Strulik, H., 2000, On endogenous growth with physical capital, human capital, and product variety', European Economic Review 44, 491-515.

Galor, O., 2005, From stagnation to growth: unified growth theory, in: P. Aghion and S. Durlauf, Handbook of Economic Growth Vol 1A, Elsevier, Amsterdam.

Galor, O., 2011, Unified Growth Theory, Princeton University Press, Princeton.

Galor, O. and Weil, D.N., 2000, Population,technology and growth: From the Malthusian regime to the demographic transition and beyond, American Economic Review 110, 806-828.

Galor, O. and Moav, O., 2002, Natural selection and the origin of economic growth, Quarterly Journal of Economics 117, 1133-1192.

Galor, O. and Moav, O., 2004, From physical to human capital accumulation: Inequality and the process of development, Review of Economic Studies 71, 1001-1026.

Galor, O. and Mountford, A., 2008, Trading population for productivity: theory and evidence, Review of Economic Studies 75, 1143-1179.

Galor, O., Moav, O., and Vollrath, D., 2009, Inequality in landownership, the emergence of humancapital promoting institutions, and the Great Divergence, Review of Economic Studies 76, 143179.

Gordon, R.J., 1999, U.S. economic growth since 1870: one big wave? American Economic Review 89, 123-128.

Grossmann, V., 2010, Entrepreneurial innovation and economic growth, Journal of Macroeconomics 31, 602-613.

Growiec, J., 2006, Fertility choice and semi-endogenous growth: where Becker meets Jones, Topics in Macroeconomics 6, Article 10.

Ha, J. and P. Howitt, 2006, Accounting for trends in productivity and R\&D, Journal of Money, Credit, and Banking 39, 733-774.

Hanushek, E.A., 1992, The trade-off between child quantity and quality, Journal of Political Economy 100, 84-117.

Herzer, D., Vollmer, S., and Strulik, H., 2012, The long-run determinants of fertility: One century of demographic change 1900-1999, Journal of Economic Growth, forthcoming. 
Heston, A., Summers, R., and Aten, B., 2011, Penn World Table Version 7.0, Center for International Comparisons of Production, Income and Prices at the University of Pennsylvania, May 2011.

Hodrick, R.J. and Prescott, E.C., 1997, Postwar U.S. business cycles: an empirical investigation, Journal of Money, Credit, and Banking 29, 1-16.

Howitt, P. 1999, Steady endogenous growth with population and R\&D inputs growing, Journal of Political Economy 107, 715-30.

Human Fertility Database, 2012, Human Fertility Database, Max Planck Institute for Demographic Research and Vienna Institute of Demography.

Jaffe, A. M. Tratjenberg, and R. Henderson, 1993, Geographic localization of knowledge spillovers as evidenced by patent citations Quarterly Journal of Economics 63, 577-598.

Jones, C.I., 1995, R\&D-based models of economic growth, Journal of Political Economy 103, 759-784.

Jones, C.I., 2001, Was an industrial revolution inevitable? Economic growth over the very long run, Advances in Macroeconomics 1, 1-43.

Jones, C.I., 2002, Sources of U.S. economic growth in a world of ideas, American Economic Review $92,220-239$.

Kelley, A.C. and Schmidt, R., 1995, Aggregate population and economic growth correlations: The role of the components of demographic change", Demography 32, 543-55.

Keller, W., 2002, Geographic localization of international technology diffusion, American Economic Review 92, 120-142.

Keller, W., 2009, International trade, foreign direct investment, and technology spillovers, NBER Working Paper 15442.

Kortum, S, 1997, Research, patenting, and technological change, Econometrica 65, 1389-1419.

Kremer, M., 1993, Population growth and technological change: one million B.C. to 1990, Quarterly Journal of Economics 108, 681-716.

Lee, R., and Mason, A., 2010, Fertility, human capital, and economic growth over the demographic transition, European Journal of Population 26, 159-182.

Li, C.-W., 2000, Endogenous vs. semi-endogenous growth in a two R\&D-sector model", Economic Journal, C109-C122.

Li, H. and Zhang, J., 2007, Do high birth rates hamper economic growth?, Review of Economics and Statistics 89, 110-117.

Maddison, A., 2001, The World Economy: A Millennial Perspective, Development Center Studies, OECD, Paris.

Madsen, J.B. and Ang, J.B. and Banerjee, R., 2010, Four centuries of British economic growth: the roles of technology and population, Journal of Economic Growth 15, 1-28.

Moav, O., 2005, Cheap children and the persistence of poverty, Economic Journal 115, 88-110. 
Mokyr, J., 2002, The Gifts of Athena, Princeton University Press, Princeton.

Myrskyla, M., Kohler, H.-P., and Billari, F.C., 2009, Advances in development reverse fertility decline, Nature 460, 741-743.

Peretto, P.F., 1998, Technological change and population growth, Journal of Economic Growth 3, 283-311.

Romer, P.M., 1990, Endogenous technological change, Journal of Political Economy 98, S71-S102.

Rosenzweig, M. 1990, Population growth and human capital investments: theory and evidence, Journal of Political Economy 98, S38-S70.

Rosenzweig, M., and K.I. Wolpin, 1980, Testing the quantity-quality fertility model: the use of twins as natural experiment, Econometrica 48, 227-240.

Segerstrom, P., 1998, Endogenous growth without scale effects, American Economic Review 88, 1290-1310.

Strulik, H., 2005, The Role of Human Capital and Population Growth in R\&D-Based Models of Economic Growth, Review of International Economics 13, 129-145.

Strulik, H. and J. Weisdorf, 2008, Population, food, and knowledge: A simple unified growth model, Journal of Economic Growth 13, 169-194.

UN, 2008, United Nations World Population Prospects: 2008 revision United Nations Department of Economic and Social Affairs, Population Division. New York.

UN, 2011, United Nations World Population Prospects: 2010 revision United Nations Department of Economic and Social Affairs, Population Division. New York. http://esa.un.org/unpd/wpp/.

U.S. National Center for Health Statistics. 2010, National Vital Statistics Reports Volume 58 (16), Births: Preliminary Data for 2008, U.S. Department of Health and Human Services.

World Bank, 2012, World Development Indicators \& Global Development Finance Database.

Young, A., 1998, Growth Without Scale Effects, Journal of Political Economy 106, 41-63. 


\section{Bisher erschienene Diskussionspapiere}

Nr. 140: Strulik, Holger; Prettner, Klaus; Prskawetz, Alexia: The Past and Future of Knowledgebased Growth, September 2012

Nr. 139: Prettner, Klaus; Trimborn, Timo: Demographic change and R\&D-based economic growth: reconciling theory and evidence, September 2012

Nr. 138: König, Jörg; Ohr, Renate: Homogeneous groups within a heterogeneous community Evidence from an index measuring European economic integration, August 2012

Nr. 137: Schwager, Robert: Student Loans in a Tiebout Model of Higher, July 2012

Nr. 136: Martínez-Zarzoso, Inmaculada: Exporting and Productivity: Evidence for Egypt and Morocco, April 2012

Nr. 135: König, Jörg; Ohr, Renate: Messung ökonomischer Integration in der Europäischen Union Entwicklung eines EU-Integrationsindexes -, April 2012

Nr. 134: Gehringer, Agnieszka: Financial liberalization, growth, productivity and capital accumulation: The case of European integration, März 2012

Nr. 133: Berner, Eike; Birg, Laura: Retailers and Consumers. The pass-through of import price changes, März 2012

Nr. 132: Gehringer, Angnieszka: Current accounts in Europe: implications of the external imbalances for the future of the common monetary policy, März 2012

Nr. 131: Ohr, Renate; Özalbayrak, Mehmet: The Euro - A „MUST“ for Small European States?, Januar 2012

Nr. 130: Zeddies, Götz: Der Euro als Triebfeder des deutschen Exports?, November 2011

Nr. 129: Geishecker, Ingo; Siedler, Thomas: Job Loss Fears and (Extreme) Party Identification: First Evidence from Panel Data, Oktober 2011

Nr. 128: König, Jörg; Ohr, Renate: Small but Beautiful? Economic Impacts of the Size of Nations in the European Union, August 2011

Nr. 127: Schüder, Stefan: Monetary Policy Trade-Offs in a Portfolio Model with Endogenous Asset Supply, Juni 2011

Nr. 126: Hiller, Sanne: The Export Promoting Effect of Emigration: Evidence from Denmark, Juni 2011

Nr. 125: Martínez-Zarzoso, Inmaculada; Voicu, Anca M.; Vidovic, Martina: CEECs Integration into Regional and Global Production Networks, Mai 2011

Nr. 124: Roth, Felix; Gros, Daniel; Nowak-Lehmann D., Felicitas: Has the Financial Crisis eroded Citizens' Trust in the European Central Bank? Panel Data Evidence for the Euro Area, 1999-2011, Mai 2011, Revised Version März 2012

Nr. 123 Dreher, Axel; Vreeland, James Raymond : Buying Votes and International Organizations, Mai 2011

Nr. 122: Schürenberg-Frosch, Hannah: One Model fits all? Determinants of Transport Costs across Sectors and Country Groups, April 2011

Nr. 121: Verheyen, Florian: Bilateral Exports from Euro Zone Countries to the US - Does Exchange Rate Variability Play a Role?, April 2011

Nr. 120: Ehlers, Tim: University Graduation Dependent on Family's Wealth, Ability and Social Status, April 2011

Nr. 119: Cho, Seo-Young; Dreher, Axel; Neumayer, Eric: The Spread of Anti-trafficking Policies Evidence from a New Index, März 2011 
Nr. 118: Cho, Seo-Young; Vadlamannati, Krishna Chaitanya: Compliance for Big Brothers: An Empirical Analysis on the Impact of the Anti-trafficking Protocol, Februar 2011

Nr. 117: Nunnenkamp, Peter; Öhler, Hannes: Donations to US based NGOs in International Development Cooperation: How (Un-)Informed Are Private Donors?, Februar 2011

Nr. 116: Geishecker, Ingo; Riedl, Maximilian: Ordered Response Models and Non-Random Personality Traits: Monte Carlo Simulations and a Practical Guide, Revised Version Februar 2012

Nr. 115: Dreher, Axel; Gassebner, Martin; Siemers, Lars-H. R.: Globalization, Economic Freedom and Human Rights, Oktober 2010

Nr. 114: Dreher, Axel; Mikosch, Heiner; Voigt, Stefan: Membership has its Privileges - The Effect of Membership in International Organizations on FDI, Oktober 2010

Nr. 113: Fuchs, Andreas; Klann, Nils-Hendrik: Paying a Visit: The Dalai Lama Effect on International Trade, Oktober 2010

Nr. 112: Freitag, Stephan: Choosing an Anchor Currency for the Pacific, Oktober 2010

Nr. 111: Nunnenkamp, Peter; Öhler, Hannes: Throwing Foreign Aid at HIV/AIDS in Developing Countries: Missing the Target?, August 2010

Nr. 110: Ohr, Renate; Zeddies, Götz: „Geschäftsmodell Deutschland“ und außenwirtschaftliche Ungleichgewichte in der EU, Juli 2010

Nr. 109: Nunnenkamp, Peter; Öhler, Hannes: Funding, Competition and the Efficiency of NGOs: An Empirical Analysis of Non-charitable Expenditure of US NGOs Engaged in Foreign Aid, Juli 2010

Nr. 108: Krenz, Astrid: La Distinction reloaded: Returns to Education, Family Background, Cultural and Social Capital in Germany, Juli 2010

Nr. 107: Krenz, Astrid: Services sectors' agglomeration and its interdependence with industrial agglomeration in the European Union, Juli 2010

Nr. 106: Krenz, Astrid; Rübel, Gerhard: Industrial Localization and Countries' Specialization in the European Union: An Empirical Investigation, Juli 2010

Nr. 105: Schinke, Jan Christian: Follow the Sun! How investments in solar power plants in Sicily can generate high returns of investments and help to prevent global warming, Juni 2010

Nr. 104: Dreher, Axel; Sturm, Jan-Egbert; Vreeland, James Raymon: Does membership on the Security Council influence IMF conditionality?, Juni 2010

Nr. 103: Öhler, Hannes; Nunnenkamp, Peter; Dreher, Axel: Does Conditionality Work? A Test for an Innovative US Aid Scheme, Juni 2010

Nr. 102: Gehringer, Agnieszka: Pecuniary Knowledge Externalities in a New Taxonomy: Knowledge Interactions in a Vertically Integrated System, Juni 2010

Nr. 101: Gehringer, Agnieszka: Pecuniary Knowledge Externalities across European Countries - are there leading Sectors?, Juni 2010

Nr. 100: Gehringer, Agnieszka: Pecuniary Knowledge Externalities and Innovation: Intersectoral Linkages and their Effects beyond Technological Spillovers, Juni 2010

Nr. 99: Dreher, Axel; Nunnenkamp, Peter; Öhler, Hannes: Why it pays for aid recipients to take note of the Millennium Challenge Corporation: Other donors do!, April 2010

Nr. 98: Baumgarten, Daniel; Geishecker, Ingo; Görg, Holger: Offshoring, tasks, and the skill-wage pattern, März 2010

Nr. 97: Dreher, Axel; Klasen, Stephan; Raymond, James; Werker, Eric: The costs of favoritism: Is politically-driven aid less effective?, März 2010

Nr. 96: Dreher, Axel; Nunnenkamp, Peter; Thiele, Rainer: Are 'New' Donors Different? Comparing the Allocation of Bilateral Aid between Non-DAC and DAC Donor Countries, März 2010 
Nr. 95: Lurweg, Maren; Westermeier, Andreas: Jobs Gained and Lost through Trade - The Case of Germany, März 2010

Nr. 94: Bernauer, Thomas; Kalbhenn, Anna; Koubi, Vally; Ruoff, Gabi: On Commitment Levels and Compliance Mechanisms - Determinants of Participation in Global Environmental Agreements, Januar 2010

Nr. 93: Cho, Seo-Young: International Human Rights Treaty to Change Social Patterns - The Convention on the Elimination of All Forms of Discrimination against Women, Januar 2010

Nr. 92: Dreher, Axel; Nunnenkamp, Peter; Thiel, Susann; Thiele, Rainer: Aid Allocation by German NGOs: Does the Degree of Public Refinancing Matter?, Januar 2010

Nr. 91: Bjørnskov, Christian; Dreher, Axel; Fischer, Justina A. V.; Schnellenbach, Jan: On the relation between income inequality and happiness: Do fairness perceptions matter?, Dezember 2009

Nr. 90: Geishecker, Ingo: Perceived Job Insecurity and Well-Being Revisited: Towards Conceptual Clarity, Dezember 2009

Nr. 89: Kühl, Michael: Excess Comovements between the Euro/US dollar and British pound/US dollar exchange rates, November 2009

Nr. 88: Mourmouras, Alex, Russel, Steven H.: Financial Crises, Capital Liquidation and the Demand for International Reserves, November 2009

Nr. 87: Goerke, Laszlo, Pannenberg, Markus: An Analysis of Dismissal Legislation: Determinants of Severance Pay in West Germany, November 2009

Nr. 86: Marchesi, Silvia, Sabani, Laura, Dreher, Axel: Read my lips: the role of information transmission in multilateral reform design, Juni 2009

Nr. 85: Heinig, Hans Michael: Sind Referenden eine Antwort auf das Demokratiedilemma der EU?, Juni 2009

Nr. 84: El-Shagi, Makram: The Impact of Fixed Exchange Rates on Fiscal Discipline, Juni 2009

Nr. 83: Schneider, Friedrich: Is a Federal European Constitution for an Enlarged European Union Necessary? Some Preliminary Suggestions using Public Choice Analysis, Mai 2009

Nr. 82: Vaubel, Roland: Nie sollst Du mich befragen? Weshalb Referenden in bestimmten Politikbereichen - auch in der Europapolitik - möglich sein sollten, Mai 2009

Nr. 81: Williamson, Jeffrey G.: History without Evidence: Latin American Inequality since 1491, Mai 2009

Nr. 80: Erdogan, Burcu: How does the European Integration affect the European Stock Markets?, April 2009

Nr. 79: Oelgemöller, Jens; Westermeier, Andreas: RCAs within Western Europe, März 2009

Nr. 78: Blonski, Matthias; Lilienfeld-Toal, Ulf von: Excess Returns and the Distinguished Player Paradox, Oktober 2008

Nr. 77: Lechner, Susanne; Ohr, Renate: The Right of Withdrawal in the Treaty of Lisbon: A game theoretic reflection on different decision processes in the EU, Oktober 2008

Nr. 76: Kühl, Michael: Strong comovements of exchange rates: Theoretical and empirical cases when currencies become the same asset, Juli 2008

Nr. 75: Höhenberger, Nicole; Schmiedeberg, Claudia: Structural Convergence of European Countries, Juli 2008

Nr. 74: Nowak-Lehmann D., Felicitas; Vollmer, Sebastian; Martinez-Zarzoso, Inmaculada: Does Comparative Advantage Make Countries Competitive? A Comparison of China and Mexico, Juli 2008

Nr. 73: Fendel, Ralf; Lis, Eliza M.; Rülke, Jan-Christoph: Does the Financial Market Believe in the Phillips Curve? - Evidence from the G7 countries, Mai 2008 
Nr. 72: Hafner, Kurt A.: Agglomeration Economies and Clustering - Evidence from German Firms, Mai 2008

Nr. 71: Pegels, Anna: Die Rolle des Humankapitals bei der Technologieübertragung in Entwicklungsländer, April 2008

Nr. 70: Grimm, Michael; Klasen, Stephan: Geography vs. Institutions at the Village Level, Februar 2008

Nr. 69: Van der Berg, Servaas: How effective are poor schools? Poverty and educational outcomes in South Africa, Januar 2008

Nr. 68: Kühl, Michael: Cointegration in the Foreign Exchange Market and Market Efficiency since the Introduction of the Euro: Evidence based on bivariate Cointegration Analyses, Oktober 2007

Nr. 67: Hess, Sebastian; Cramon-Taubadel, Stephan von: Assessing General and Partial Equilibrium Simulations of Doha Round Outcomes using Meta-Analysis, August 2007

Nr. 66: Eckel, Carsten: International Trade and Retailing: Diversity versus Accessibility and the Creation of "Retail Deserts", August 2007

Nr. 65: Stoschek, Barbara: The Political Economy of Enviromental Regulations and Industry Compensation, Juni 2007

Nr. 64: Martinez-Zarzoso, Inmaculada; Nowak-Lehmann D., Felicitas; Vollmer, Sebastian: The Log of Gravity Revisited, Juni 2007

Nr. 63: Gundel, Sebastian: Declining Export Prices due to Increased Competition from NIC Evidence from Germany and the CEEC, April 2007

Nr. 62: Wilckens, Sebastian: Should WTO Dispute Settlement Be Subsidized?, April 2007

Nr.61: Schöller, Deborah: Service Offshoring: A Challenge for Employment? Evidence from Germany, April 2007

Nr. 60: Janeba, Eckhard: Exports, Unemployment and the Welfare State, März 2007

Nr. 59: Lambsdoff, Johann Graf; Nell, Mathias: Fighting Corruption with Asymmetric Penalties and Leniency, Februar 2007

Nr. 58: Köller, Mareike: Unterschiedliche Direktinvestitionen in Irland - Eine theoriegestützte Analyse, August 2006

Nr. 57: Entorf, Horst; Lauk, Martina: Peer Effects, Social Multipliers and Migrants at School: An International Comparison, März 2007 (revidierte Fassung von Juli 2006)

Nr. 56: Görlich, Dennis; Trebesch, Christoph: Mass Migration and Seasonality Evidence on Moldova's Labour Exodus, Mai 2006

Nr. 55: Brandmeier, Michael: Reasons for Real Appreciation in Central Europe, Mai 2006

Nr. 54: Martínez-Zarzoso, Inmaculada; Nowak-Lehmann D., Felicitas: Is Distance a Good Proxy for Transport Costs? The Case of Competing Transport Modes, Mai 2006

Nr. 53: Ahrens, Joachim; Ohr, Renate; Zeddies, Götz: Enhanced Cooperation in an Enlarged EU, April 2006

Nr. 52: Stöwhase, Sven: Discrete Investment and Tax Competition when Firms shift Profits, April 2006

Nr. 51: Pelzer, Gesa: Darstellung der Beschäftigungseffekte von Exporten anhand einer InputOutput-Analyse, April 2006

Nr. 50: Elschner, Christina; Schwager, Robert: A Simulation Method to Measure the Tax Burden on Highly Skilled Manpower, März 2006

Nr. 49: Gaertner, Wulf; Xu, Yongsheng: A New Measure of the Standard of Living Based on Functionings, Oktober 2005 
Nr. 48: Rincke, Johannes; Schwager, Robert: Skills, Social Mobility, and the Support for the Welfare State, September 2005

Nr. 47: Bose, Niloy; Neumann, Rebecca: Explaining the Trend and the Diversity in the Evolution of the Stock Market, Juli 2005

Nr. 46: Kleinert, Jörn; Toubal, Farid: Gravity for FDI, Juni 2005

Nr. 45: Eckel, Carsten: International Trade, Flexible Manufacturing and Outsourcing, Mai 2005

Nr. 44: Hafner, Kurt A.: International Patent Pattern and Technology Diffusion, Mai 2005

Nr. 43: Nowak-Lehmann D., Felicitas; Herzer, Dierk; Martínez-Zarzoso, Inmaculada; Vollmer, Sebastian: Turkey and the Ankara Treaty of 1963: What can Trade Integration Do for Turkish Exports, Mai 2005

Nr. 42: Südekum, Jens: Does the Home Market Effect Arise in a Three-Country Model?, April 2005

Nr. 41: Carlberg, Michael: International Monetary Policy Coordination, April 2005

Nr. 40: Herzog, Bodo: Why do bigger countries have more problems with the Stability and Growth Pact?, April 2005

Nr. 39: Marouani, Mohamed A.: The Impact of the Mulitfiber Agreement Phaseout on Unemployment in Tunisia: a Prospective Dynamic Analysis, Januar 2005

Nr. 38: Bauer, Philipp; Riphahn, Regina T.: Heterogeneity in the Intergenerational Transmission of Educational Attainment: Evidence from Switzerland on Natives and Second Generation Immigrants, Januar 2005

Nr. 37: Büttner, Thiess: The Incentive Effect of Fiscal Equalization Transfers on Tax Policy, Januar 2005

Nr. 36: Feuerstein, Switgard; Grimm, Oliver: On the Credibility of Currency Boards, Oktober 2004

Nr. 35: Michaelis, Jochen; Minich, Heike: Inflationsdifferenzen im Euroraum - eine Bestandsaufnahme, Oktober 2004

Nr. 34: Neary, J. Peter: Cross-Border Mergers as Instruments of Comparative Advantage, Juli 2004

Nr. 33: Bjorvatn, Kjetil; Cappelen, Alexander W.: Globalisation, inequality and redistribution, Juli 2004

Nr. 32: Stremmel, Dennis: Geistige Eigentumsrechte im Welthandel: Stellt das TRIPs-Abkommen ein Protektionsinstrument der Industrieländer dar?, Juli 2004

Nr. 31: Hafner, Kurt: Industrial Agglomeration and Economic Development, Juni 2004

Nr. 30: Martinez-Zarzoso, Inmaculada; Nowak-Lehmann D., Felicitas: MERCOSUR-European Union Trade: How Important is EU Trade Liberalisation for MERCOSUR's Exports?, Juni 2004

Nr. 29: Birk, Angela; Michaelis, Jochen: Employment- and Growth Effects of Tax Reforms, Juni 2004

Nr. 28: Broll, Udo; Hansen, Sabine: Labour Demand and Exchange Rate Volatility, Juni 2004

Nr. 27: Bofinger, Peter; Mayer, Eric: Monetary and Fiscal Policy Interaction in the Euro Area with different assumptions on the Phillips curve, Juni 2004

Nr. 26: Torlak, Elvisa: Foreign Direct Investment, Technology Transfer and Productivity Growth in Transition Countries, Juni 2004

Nr. 25: Lorz, Oliver; Willmann, Gerald: On the Endogenous Allocation of Decision Powers in Federal Structures, Juni 2004

Nr. 24: Felbermayr, Gabriel J.: Specialization on a Technologically Stagnant Sector Need Not Be Bad for Growth, Juni 2004

Nr. 23: Carlberg, Michael: Monetary and Fiscal Policy Interactions in the Euro Area, Juni 2004

Nr. 22: Stähler, Frank: Market Entry and Foreign Direct Investment, Januar 2004 
Nr. 21: Bester, Helmut; Konrad, Kai A.: Easy Targets and the Timing of Conflict, Dezember 2003

Nr. 20: Eckel, Carsten: Does globalization lead to specialization, November 2003

Nr. 19: Ohr, Renate; Schmidt, André: Der Stabilitäts- und Wachstumspakt im Zielkonflikt zwischen fiskalischer Flexibilität und Glaubwürdigkeit: Ein Reform-ansatz unter Berücksichtigung konstitutionen- und institutionenökonomischer Aspekte, August 2003

Nr. 18: Ruehmann, Peter: Der deutsche Arbeitsmarkt: Fehlentwicklungen, Ursachen und Reformansätze, August 2003

Nr. 17: Suedekum, Jens: Subsidizing Education in the Economic Periphery: Another Pitfall of Regional Policies?, Januar 2003

Nr. 16: Graf Lambsdorff, Johann; Schinke, Michael: Non-Benevolent Central Banks, Dezember 2002

Nr. 15: Ziltener, Patrick: Wirtschaftliche Effekte des EU-Binnenmarktprogramms, November 2002

Nr. 14: Haufler, Andreas; Wooton, Ian: Regional Tax Coordination and Foreign Direct Investment, November 2001

Nr. 13: Schmidt, André: Non-Competition Factors in the European Competition Policy: The Necessity of Institutional Reforms, August 2001

Nr. 12: Lewis, Mervyn K.: Risk Management in Public Private Partnerships, Juni 2001

Nr. 11: Haaland, Jan I.; Wooton, Ian: Multinational Firms: Easy Come, Easy Go?, Mai 2001

Nr. 10: Wilkens, Ingrid: Flexibilisierung der Arbeit in den Niederlanden: Die Entwicklung atypischer Beschäftigung unter Berücksichtigung der Frauenerwerbstätigkeit, Januar 2001

Nr. 9: Graf Lambsdorff, Johann: How Corruption in Government Affects Public Welfare - A Review of Theories, Januar 2001

Nr. 8: Angermüller, Niels-Olaf: Währungskrisenmodelle aus neuerer Sicht, Oktober 2000

Nr. 7: Nowak-Lehmann, Felicitas: Was there Endogenous Growth in Chile (1960-1998)? A Test of the AK model, Oktober 2000

Nr. 6: Lunn, John; Steen, Todd P.: The Heterogeneity of Self-Employment: The Example of Asians in the United States, Juli 2000

Nr. 5: Güßefeldt, Jörg; Streit, Clemens: Disparitäten regionalwirtschaftlicher Entwicklung in der EU, Mai 2000

Nr. 4: Haufler, Andreas: Corporate Taxation, Profit Shifting, and the Efficiency of Public Input Provision, 1999

Nr. 3: Rühmann, Peter: European Monetary Union and National Labour Markets, September 1999

Nr. 2: Jarchow, Hans-Joachim: Eine offene Volkswirtschaft unter Berücksichtigung des Aktienmarktes, 1999

Nr. 1: Padoa-Schioppa, Tommaso: Reflections on the Globalization and the Europeanization of the Economy, Juni 1999

Alle bisher erschienenen Diskussionspapiere zum Download finden Sie im Internet unter: http://www.uni-goettingen.de/de/60920.html. 